\title{
ARQUITETURA E ARQUIVO. CONTRIBUTOS PARA UMA COMPREENSÃO DAS ESTRUTURAS EM NEGATIVO DA PRÉ-HISTÓRIA RECENTE DAS COLINAS ENTRE OS BARRANCOS DA MORGADINHA E DA LAJE (SERPA, BEJA)
}

\author{
SÉRGIO ALEXANDRE GOMES ${ }^{(1)} \&$ LÍDIA BAPTISTA ${ }^{(2)}$
}

Resumo:

Neste texto analisamos a tradição de construção em negativo durante a Pré-história Recente no Sul de Portugal. Os vestígios que estudamos foram identificados no âmbito de intervenções realizadas a propósito da execução do Bloco de Rega de Brinches-Enxoé (Serpa). Num primeiro momento, discutimos as possibilidades de, na base empírica decorrente de tais intervenções, reconhecer uma unidade de estudo cuja inteligibilidade possa corresponder-se com o estudo da monumentalização da paisagem durante a Pré-história Recente. Uma vez delineada a unidade de estudo, procedemos à sua apresentação tendo em conta a morfologia, a distribuição espacial, o enquadramento cronológico e os enchimentos das estruturas. Por fim, propomos que se problematize estes vestígios como formalizações materiais do entrelaçamento de práticas de arquitetura e de práticas de arquivo, no qual são negociados o(s) horizonte(s) sentido que sustentam a construção de paisagens monumentais.

Palavras-chave: Arquitetura, Arquivo; Monumentalização da paisagem, Estruturas em negative, Pré-história Recente, Sul de Portugal

Abstract:

\begin{abstract}
Architecture and Archive. Towards an understanding of the Late Prehistory negative structures from the hills between Barranco da Morgadinha and Barranco da Laje (Serpa, Beja - South of Portugal)

This article focus on the negative construction tradition of the Late Prehistory Prehistoric in the South of Portugal. The features in study were identified during the archaeological interventions realized during the construction of the Bloco de Rega de Brinches-Enxoé (Serpa). Firstly, we discuss the possibilities to use the empirical basis produced in such interventions to formulate a unit of study, whose intelligibility may answer to the discussion of the monumentalization of the landscape during Late Prehistory. After limiting the unit of study, we present the features regarding their morphology, spatial distribution, chronology and the structures fills. Finally, we propose a discussion of these structures as material configurations of an interweaving of architecture and archive practices in which are negotiated the horizon(s) of meaning holding the construction of monumental landscapes.
\end{abstract}

Keywords: Architecture; Archive; Monumentalization of the landscape; Negative structures; Late Prehistory; South of Portugal

Received: 3 March, 2017; Accepted: 16 November, 2017

\section{INTRODUÇÃO}

O presente texto tem como objetivo a apresentação e a discussão das viabilidades de estudo de uma base empírica produzida no âmbito de intervenções arqueológicas de salvamento desenvolvidas no âmbito do Bloco de Rega de Brinches -Enxoé (Serpa, Beja). Estes trabalhos foram promovidos pela EDIA S.A. e executados pela equipa da Arqueologia \& Património Lda. A análise preliminar dos resultados obtidos permite constatar a presença de vestígios da Pré-história Recente, designadamente estruturas em negativo. Considerando o elevado número de ocorrências e a sua distribuição pelas diferentes áreas de afetação do projeto, pensamos ser necessário encontrar um modo de delinear esta base empírica enquanto unidade de estudo que exceda a lógica de gestão patrimonial no âmbito da qual foi produzida. No Ponto 2, apresentamos a dinâmica da unidade de estudo discutida neste artigo que, de um ponto de vista geográfico, foi delimitada tendo em conta os Barrancos da Morgadinha e da Laje, tributários da margem sul da Ribeira do Enxoé (Fig. 1 e 2). Como veremos, tal delimitação permite orientar o enquadramento dos vestígios na problematização da monumentalização da paisagem durante a Préhistória Recente (e.g., CRIADO-BOADO 1993; JORGE 1999; VALERA 2012). No Ponto 3, apresentamos os vestígios arqueológicos que compõem a unidade de estudo, focando, de modo sumário, na sua distribuição espacial e enquadramento cronológico, na variabilidade morfológica das estruturas e nas sequências de enchimento. Algumas das estruturas apresentam níveis de enchimento intencionais, funcionando como locais de deposição de diferentes categorias de materiais e de inumação de cadáveres humanos e animais. Estes enchimentos, e a sua relação com os dispositivos arquitetónicos em que se encontram, relembram as relações entre a prática de arquitetura e a prática de arquivo, que discutimos no Ponto 4. Esta associação entre arquivo e arquitetura será discutida a partir do pensamento de J. DERRIDA (2001), guiando-nos na elaboração de uma orientação teórico-metodológica para a análise do papel destas construções na monumentalização da paisagem durante a Pré-história Recente.

\footnotetext{
${ }^{(1)}$ Centro de Estudos em Arqueologia, Artes e Ciências do Património - Universidade de Coimbra. sergioalexandregomes@gmail.com

${ }^{(2)}$ Centro de Estudos em Arqueologia, Artes e Ciências do Património - Universidade de Coimbra | Arqueologia e Patimónio Lda. lidiabap@gmail.com
} 


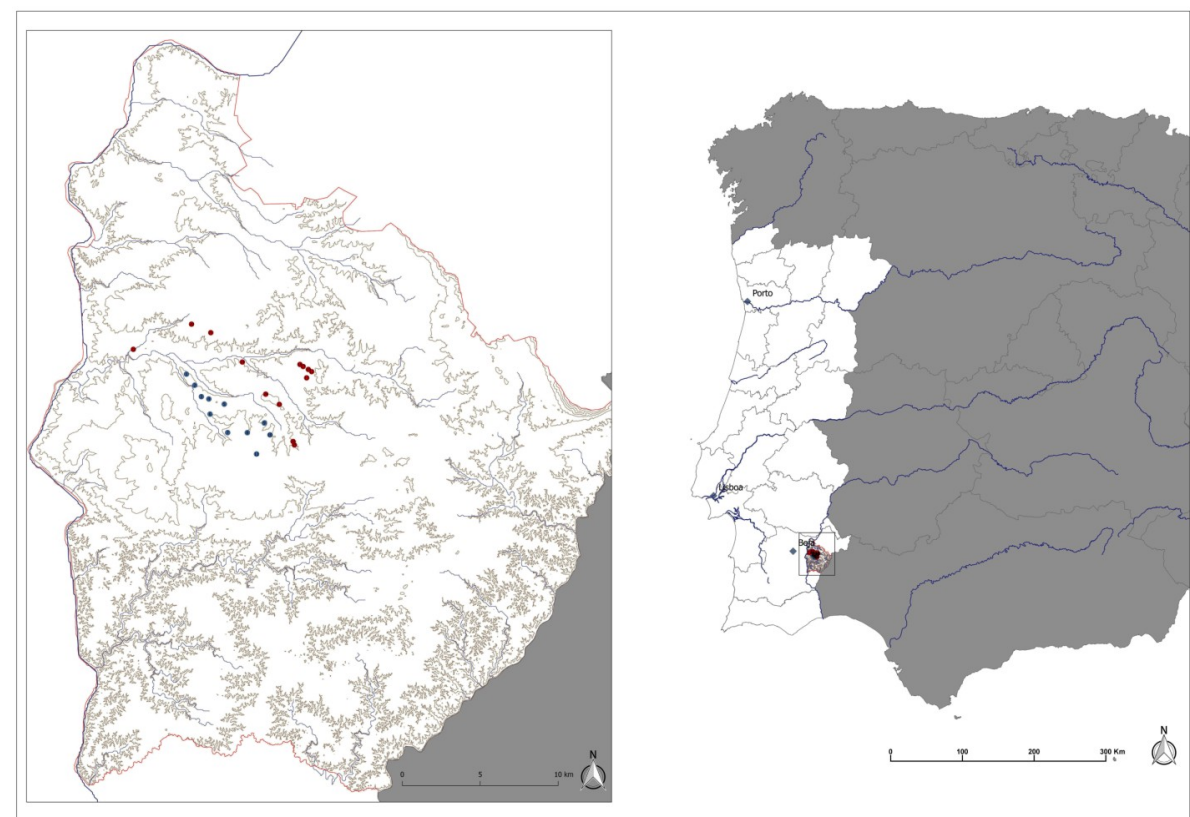

Fig. 1. Localização das ocorrências patrimoniais, com vestígios da Pré-história Recente, intervencionados no âmbito do Bloco de Rega de Brinches-Enxoé no concelho de Serpa.

Fig. 1. Location of the Late Prehistory sites identified during the construction of the Bloco de Rega de Brinches -Enxoé (Serpa).

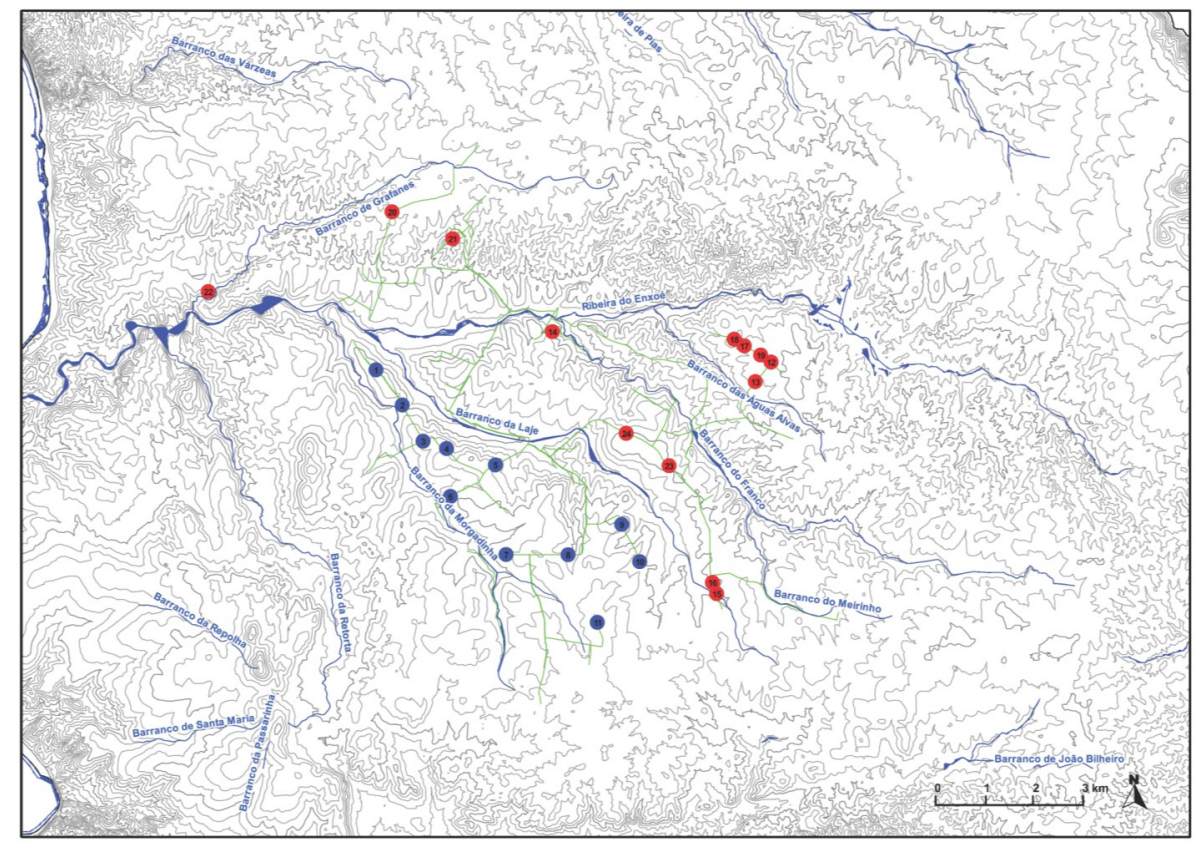

Fig. 2. Localização da unidade de estudo na bacia hidrográfica da Ribeira do Enxoé.

Unidade de estudo (a azul): 1. Horta da Morgadinha (CNS 13194); 2. Horta da Morgadinha 1 (CNS 31809); 3. Horta da Morgadinha 2 (CNS 31513); 4. Espicharrabo 4 (CNS 13229); 5. Alcaria 4 (CNS 31348); 6. Alcaria 5 (CNS 31349); 7. Cidade das Rosas 4 (CNS 31521); 8. Maria da Guarda 3 (CNS 31517); 9. Laje 2 (CNS 31518); 10. Monte da Laje (CNS 31519); 11. Vale de Águas 3 (CNS 31346) | Restantes sítios (a vermelho) 12. Águas Alvas 1 (CNS 31357); 13. Águas Alvas (CNS 31356); 14. Escalfa Cães 1 (CNS 13204); 15. Folha da Vereda 1 (CNS 13257); 16. Meirinho 4 (CNS 31280); 19. Monte da Chilra (CNS 31353); 17. Monte da Chilra 1 (CNS 31352); 18. Monte da Chilra 2 (CNS 31351); 20. Montinhos 3 (CNS 31811); 21. Montinhos 6 (CNS 31350); 22. Salsa 3 (CNS 23012); 23. Santo Estevão 1 (CNS 31514); 24. Torre Velha 12 (CNS 31516). Linha verde - implantação das condutas do projeto. Fig. 2. Location of the unit of study at the Ribeira do Enxoé hydrographic basin. Blue - Unit of study; Red Other sites excavated during the construction of Bloco de Rega de Brinches-Enxoé; Green line - pipeline project. 


\section{A DEFINIĈ̃̃ DA UNIDADE DE ESTUDO}

Entre 2009 e 2010, a equipa da Arqueologia \& Património Lda. desenvolveu um conjunto de intervenções no âmbito dos trabalhos de minimização de impactes patrimoniais durante a execução do Bloco de Rega de Brinches-Enxoé (município de Serpa). Os trabalhos enquadravam-se numa lógica de salvaguarda do património arqueológico, correspondendo a uma medida que visava, em fase de obra, assegurar a escavação de contextos arqueológicos identificados pelas equipas de acompanhamento arqueológico. A implementação destas medidas (acompanhamento arqueológico e escavação) tinha como objetivo colmatar o diagnóstico (prospeção e sondagens) desenvolvido anteriormente (BAPTISTA \& GOMES 2012a). Os trabalhos desenvolvidos neste projeto e noutros semelhantes contribuíram decisivamente para refazer o conhecimento e as condições de pesquisa do Baixo Alentejo. Com efeito, da implementação destas medidas resultou uma base empírica que contribuiu para o desenvolvimento de projetos de pesquisa em curso e para a emergência de novas questões (e.g., Martinho 2014; Melro \& Deus 2014; SILVA 2014). No caso do estudo da Préhistória Recente, estes trabalhos permitiram a intervenção em diferentes zonas que correspondiam a vazios de pesquisa, ou pontuadas por pequenos trabalhos, e a identificação de contextos arqueológicos que convocam um conjunto de problemáticas diversificado, cujo desenvolvimento permite complexificar o conhecimento que podemos produzir acerca das comunidades pré-históricas que habitaram o Baixo Alentejo (e.g., BAPTISTA \& GOMES 2013a; VALERA et al. 2014).

Considerando que as intervenções arqueológicas realizadas nestes projetos obedecem a uma lógica patrimonial animada pela implementação de medidas de minimização de impacte, é necessário repensar a inteligibilidade da amostra que daí resulta. Com efeito, a uma amostragem gerada numa lógica que associa áreas de afetação do projeto e salvaguarda pelo registo, é necessário contrapor uma dinâmica de pesquisa que permita a deslocação das bases empíricas produzidas para outros campos analíticos. Um dos caminhos possíveis é ensaiar uma problematização de tais amostragens em função de quadros conceptuais que privilegiem uma abordagem espacial, na qual seja possível equacionar exercícios de delimitação que desconstruam a unidade das amostragens decorrentes das intervenções e viabilizem outra(s) unidade(s), mais profícuas de um ponto de vista da pesquisa. Esta é uma possibilidade que explora a articulabilidade (ZEMELMAN 2003 ${ }^{1}$ ) da base empírica que temos a nosso dispor. Uma possibilidade de abordagem que, pretendendo exceder os limites traçados por uma lógica de intervenção desajustada de um plano de pesquisa concreto, explora a espacialidade das amostragens como forma de gerar unidades de pesquisa cuja coerência se corresponde com um determinado inquérito e, assim, com uma redefinição dos limites e das possibilidades que se pode (re)conhecer numa realidade empírica produzida numa experiência prévia ${ }^{2}$.

Esta dinâmica de redefinição das unidades de estudo trespassa todo o processo arqueológico. A este propósito, refira-se, a título de exemplo, o pensamento de G. LUCAS (2012) acerca da "operação arqueológica". O autor perspetiva a prática arqueológica como uma mobilização de agentes humanos, orgânicos e inorgânicos mediada por uma relação entre os sítios arqueológicos e os seus projetos de arquivo. Nesta mediação, são desenvolvidas distintas atividades de (re) materialização dos vestígios do passado em coleções com diferentes ordens. Este trabalho de (re)materialização é entendido pelo autor enquanto prática de tradução, na qual a singularidade da base empírica é colocada em diálogo com um conjunto articulado de distintos programas de intervenção e análise. Neste processo, são forjadas unidades de estudo continuamente (des)articuladas consoante as analíticas que se pretende desenvolver ${ }^{3}$. Consideremos, por exemplo, o enchimento de uma estrutura em negativo onde ocorre um conjunto artefactual constituído por elementos cerâmicos, líticos e metálicos, distribuídos por diferentes depósitos. Estas ocorrências formam coleções que podem ser definidas pela categoria de material por forma a viabilizar uma análise tecnológica. Porém, de um ponto de vista da análise da sua distribuição estratigráfica, tais coleções de artefactos seriam (des)articuladas para dar lugar à formação de outras coleções cuja unidade se define pelo depósito de proveniência. $\mathrm{Ou}$, no seu conjunto, todos os constituintes de uma mesma estrutura podem formar uma coleção que viabilize a sua comparação com outras estruturas e tentar estabelecer um padrão de variabilidade. As unidades de estudo são (des)articuladas, deste modo, através do estudo que se pretende desenvolver; um

${ }^{1}$ Para H. Zemelmen, a "articulabilidade assenta na possibilidade de, a partir do fragmentário e do particular, com base em relações necessárias, dar forma a um horizonte de sentido mais rico em alternativas de construção pelos sujeitos. Poderia defender-se, no plano metodológico, que a articulabilidade define um modo de construir a identidade de um fenómeno através da sua inclusão numa articulação mais ampla, transgredindo os limites de uma situação inicial. Isto será assim com a condição de partirmos do pressuposto de que qualquer fenómeno faz parte de uma articulação, constituída historicamente, o que significa que qualquer recorte desse fenómeno obriga a considerar com parte da sua determinação o que, porém, lhe é alheio. Esta é uma forma de abordar o indeterminado como o que excede os limites de uma situação definida" (2003: 445, ver também Zemelman 2011, 2012a, 2012b).

${ }^{2}$ Sobre a necessidade de recontextualização e recondução da pesquisa em contexto de arqueologia de salvamento ver, por exemplo, o estudo desenvolvido a propósito do Bloco 5 do Plano de Minimização de Impactes sobre o Património Arqueológico na área do regolfo de Alqueva (Valera 2013).

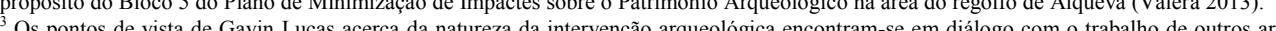
salientar as obras de M. Shanks (1992, 2012), A. Jones (2002) e M. Edgeworth (2003, 2006), por exemplo. Em Portugal, refira-se, também a título de exemplo, os textos de S. Jorge (1998a, 1998b), V. Jorge (2003), J. Rebuge (2004), A. C. Valera (2008) e A. Vale (2015). 
estudo definido, entre outros aspetos, por procedimentos de pesquisa específicos e escalas de análise.

No caso da unidade de estudo que se analisa neste artigo (Fig. 2), a sua definição partiu das amostras produzidas nas intervenções ${ }^{4}$, equacionando-as, como já referimos, de um ponto de vista espacial. Assim, privilegiando-se uma tradição arquitetónica específica da Pré-história Recente (as estruturas em negativo) e cruzando-a com elementos que pontuam a geografia local, os Barrancos da Morgadinha e da Laje, foi possível congregar vestígios espacialmente descontínuos que, de um ponto de vista arqueológico, constituem uma coleção coerente, isto é, com uma inteligibilidade passível de viabilizar uma linha de estudo. A seleção destes elementos da paisagem teve em consideração o modo como a tradição arquitetónica pode estabelecer um diálogo com a paisagem. Num artigo acerca do papel dos fossos sinuosos no processo de monumentalização da paisagem durante a Pré-história Recente do Sul de Portugal, A. C. VALERA (2012) enfatiza a importância de se considerar o modo como os distintos elementos que participam na constituição de uma cosmovisão pré-histórica podem estar em relação com o design de tais dispositivos arquitetónicos. Um design que pode estar em diálogo com uma geografia astronómica (ciclos solares e ciclos lunares, por exemplo), com as especificidades do relevo onde se implantam estes dispositivos e com a iconografia da arte rupestre (ibid.: 36). No caso que o autor se encontra a analisar, há a sugestão de uma relação de mimetismo entre o design dos recintos e a sinuosidade dos elementos que definem a geografia da área onde se encontram implantados. Ou seja, a sinuosidade dos recintos corresponde-se com o ondulado do relevo e o serpenteado das linhas de água, podendo a configuração destes elementos ter servido de eixo ordenador da prática arquitetónica. No caso da unidade de estudo em discussão, tal relação de mimetismo parece não ser tão evidente. Porém, para além desta relação de mimetismo, os mesmos elementos referidos por A.C. VALERA (ibid.) podem formalizar uma relação diferente com as estruturas em negativo. $\mathrm{O}$ serpenteado das linhas de água e ondulado das colinas podem ter funcionado como limites, e não como arquétipo de configuração, a partir dos quais se estabelece o ordenamento da construção das estruturas. Esta hipótese pareceu-nos mais apropriada à realidade que nos encontramos a estudar. Com efeito, ainda que o atual estado do conhecimento das plantas de cada uma das ocorrências patrimoniais seja parcial, não foi identificada qualquer construção que pareça desempenhar uma função de delimitação das áreas onde ocorrem as estruturas ${ }^{5}$. Assim, é de considerar que tal função ordenadora podia corres- ponder-se com um dos elementos da paisagem: a topografia das colinas onde se implantam as estruturas; os barrancos, ao longo dos quais se distribuem as ocorrências patrimoniais; ou a articulação destes dois elementos.

Perante estas possibilidades para (des) articularmos a base empírica disponível, optamos por privilegiar os barrancos enquanto modo de delimitação espacial da unidade de estudo. Esta opção foi tomada considerando quatro razões. A primeira razão prende-se ao facto dos barrancos da Morgadinha e da Laje definirem uma área bem delimitada por cursos de água que nascem no sopé aplanado da serrania de Serpa e desaguam na Ribeira do Enxoé. A segunda razão é sugerida pelo relevo entre os dois barrancos, que se caracteriza pelo encadeamento de elevações de encostas suaves. Porém, é de referir, que este traço geral do relevo apresenta variantes: a montante dos barrancos, a área é aplanada, sendo que o encaixe e o traçado dos barrancos vão progressivamente definindo, em direção a jusante, elevações mais acentuadas e de encostas mais inclinadas. Tal variabilidade não coloca em causa a unidade, pelo contrário, reforça o modo como os diferentes barrancos que correm em direção à Ribeira do Enxoé definem unidades de encadeados de pequenas colinas que se demarcam entre si. As duas primeiras razões estão, então, relacionadas com a coerência geográfica que podemos reconhecer na área delimitada pelos barrancos.

A terceira e quarta razões dizem respeito as questões de orientação teórico-metodológica. A terceira razão constitui-se na consideração do modo como os barrancos que correm para a Ribeira do Enxoé modelam a paisagem, circunscrevendo outros encadeamentos de pequenas elevações, nos quais se regista também a presença de estruturas em negativo. Assim, o uso dos barrancos enquanto limites para a formulação da presente unidade de estudo permite a formulação de unidades semelhantes, viabilizando, por exemplo, exercícios de comparação necessários à compreensão de eventuais regularidades e especificidades. Com efeito, no âmbito dos trabalhos de arqueologia desenvolvidos no âmbito da minimização de impactes dos vários projetos da EDIA, foi possível verificar a existência de outras estações de cronologia pré-histórica nas colinas que são circunscritas pelos outros barrancos que desaguam na Ribeira de Enxoé. Este modelado contrasta, por sua vez, com o da margem norte, onde se regista também a presença de estruturas em negativo de cronologia pré-histórica. Nesta margem, o relevo desenvolve-se, tendencialmente, como um maciço escalonado em elevações

\footnotetext{
${ }^{4} \mathrm{Na}$ lógica de gestão patrimonial em que foram produzidas, as amostragens eram designadas por ocorrências patrimoniais. No equacionamento desta unidade, embora existisse uma preocupação de integrar vestígios espacialmente descontínuos, a preocupação era de dar uma resposta a orientações administrativas e burocráticas que enquadravam e regulavam os trabalhos arqueológicos.

5 burocráticas que enquadravam e regulavam os trabahos arqueologicos.
Á semelhança do que acontece, por exemplo, em Montinhos 6, onde a área de intervenção abarcou quase duas colinas, nas quais não foi identificado qualquer dispositivo a delimitar a área de dispersão das estruturas. Em contrapartida, verificou-se que a maioria das estruturas ocorria no topo dessas colinas, sugerindo, deste modo, uma relação entre a localização das estruturas e o relevo das colinas onde foram construídas (Baptista 2013).
} 
de planta irregular, entre as quais não existem barrancos, estabelecendo, assim, outras condições para a definição de unidades de estudo com as quais se possa proceder à (des)articulação da base empírica. Para além da operacionalidade metodológica que o equacionamento desta unidade de estudo viabiliza a uma escala local, podemos também pensar nas suas possibilidades de potenciar a sua comparação com outras tradições arquitetónicas. Tal comparação contribui para a complexificação das questões e dos métodos de analisar a delimitação espacial, a organização territorial e a ordem social, por exemplo, que orientam o estudo deste tipo de dispositivos.

Por último, a quarta razão prende-se com as possibilidades interpretativas que a unidade de estudo pode aportar à discussão da monumentalização da paisagem durante a Pré-história Recente, referida por A.C. Valera acerca dos recintos sinuoSos (VALERA 2012; ver também JORGE et al. 2006a). Tal tópico de discussão constitui-se numa dinâmica analítica designada como dwelling perspective pelo antropólogo T. INGOLD (2000). De um modo muito sumário, esta perspetiva traz o pensamento filosófico de M. HEIDEGGER (e.g. 1971) ao estudo das comunidades pré-históricas. Para HEIDEGGER (ibid.) a ação humana é representada enquanto um entrelaçamento com a mundanidade onde decorre e com a qual estabelece uma relação de cuidado. Nesta relação, a ação humana não é uma transformação pautada pela instrumentalização de um mundo inerte, mas uma ação que, acompanhando o devir do mundo, se entrelaça nesse devir no sentido cuidar das condições de transformação. Uma transformação que, simultaneamente, orienta a ação humana e é orientada pela ação humana. Tal diálogo, uma vez transportado para a discussão das comunidades pré-históricas, incentiva à discussão das práticas dessas comunidades como práticas de transformação, na qual se jogam as possibilidades de refazer as condições de ação. A arquitetura seria, neste caso, uma transformação de pré-existências, na qual se refaz as possibilidades de experienciar o espaço e a ação (ver também BARRETT 1994a, 1994b; PeArson \& Richards 1994). Assim, os dispositivos arquitetónicos são plataformas que potenciam e entrecruzam as condições de uma realidade pré-existente e as condições de uma realidade ainda em construção e, como tal, aberta ao devir. Neste sentido, a unidade geográfica e arqueológica que equacionamos neste artigo, serve-nos de ponto de partida para questionarmos estas possibilidades. Ou seja, parte-se de a hipótese das colinas circuns- critas pelos barrancos terem atuado como uma préexistência nas quais se encontravam lançadas as condições para serem experimentadas como unidade de construção. Face a tal unidade de transformação, a construção de estruturas em negativo corresponde a uma formalização arquitetónica da relação de cuidado que as comunidades pré-históricas possam ter desenvolvido com as condições de tal unidade. Nessa relação de cuidado ter-se-ia processado uma monumentalização da paisagem na qual se joga com as possibilidades de devir das comunidades pré -históricas. Um devir que, pela prática da arquitetura, as comunidades tentam orientar pela formalização de espaços $\mathrm{em}$ construção. São espaços $\mathrm{em}$ construção nos quais se refazem as condições das relações de cuidado. Uma monumentalização em que laço social e paisagem se entrelaçam na negociação do(s) sentido(s) que ordenam o mundo e tudo aquilo que se ai se congrega e consigna. Mais à frente, voltaremos a estas questões, discutindo as práticas de arquitetura e arquivo que podemos reconhecer com a base empírica disponível.

\section{BREVE CARACTERIZAÇ̃̃O DOS RESULTA- DOS OBTIDOS NAS INTERVENÇÕES ARQUEOLÓGICAS}

$\mathrm{Na}$ área da unidade de estudo, a execução do projeto do Bloco de Rega de Brinches-Enxoé contemplava a abertura de um conjunto de valas de implantação de tubagens e de limpeza/arranjo dos Barrancos da Morgadinha e da Laje. O projeto desenvolvia-se num traçado constituído por segmentos de reta articulados, contemplando a abertura de valas de implantação de condutas perpendiculares às linhas de água e valas com um traçado, mais ou menos, paralelo a estes elementos, que se localizam preferencialmente no topo das colinas. Os trabalhos de acompanhamento arqueológico permitiram a identificação de várias áreas onde ocorrem estruturas em negativo de cronologia pré-histórica, que foram agrupadas em onze ocorrências patrimoniais (Fig. 2). Estes contextos, foram identificados após a remoção das terras de lavra, no topo do substrato geológico $^{6}$ (Fig. 3). De um ponto de vista estratigráfico, estes vestígios aparecem, então, sem associação a uma sequência estratigráfica que contribua para a sua articulação com eventuais resíduos do seu processo de construção ${ }^{7}$. Acresce referir que, em alguns casos, as estruturas estabelecem relações estratigráficas diretas entre si, sendo possível equacionar, pontualmente, um faseamento construtivo.

\footnotetext{
${ }^{6}$ De um ponto de vista geológico, a unidade de estudo abrange uma área onde as formações dominantes são os Pórfiros de Baleizão e o Complexo gabrodiorítico de Cuba.

${ }^{7}$ Relativamente a este aspeto, deve, porém, considerar-se os constrangimentos da observação em trabalhos de acompanhamento de escavações mecânicas. Ainda que se proceda a uma sistemática limpeza dos taludes, é possível que tais depósitos onde se abram as estruturas não sejam identificados nestes procedimentos. Simultaneamente, considerando a afetação dos terrenos em trabalhos de lavra mecânica, também é possível que tal depósito tenha sido desmantelado, podendo estar conservado em áreas que não foram alvo de intervenção. Note-se também que, relativamente à afetação dos trabalhos de lavra, é de referir que, em muitos casos, não se identificaram vestígios de superfície em trabalhos de prospeção prévios à obra que poderiam remeter para a afetação de tal depósito. A existência ou não, de uma sequência estratigráfica mais complexa do que a observada, e que possa contextualizar as estruturas, é uma questão a ter conta, designadamente em futuras intervenções que possam contemplar um inquérito e procedimentos de escavação ajustados às exigências desta problematização.
} 
Perante a realidade acima descrita, privilegiaremos a análise da distribuição espacial das estruturas como forma de constituir conjuntos articulados de estruturas. Como veremos, muitas das ocorrências patrimoniais correspondem a longos segmentos de reta pontuados por estruturas ou grupos de estruturas, apresentando relações de dis- tância que podem ser usadas como hipótese de trabalho para o desenvolvimento do seu estudo. A par disto, teremos também em consideração a análise das componentes artefactuais provenientes dos enchimentos como estratégia de inserção cronológica ${ }^{8}$ e, assim, de afinação das áreas formadas na análise da distribuição espacial.

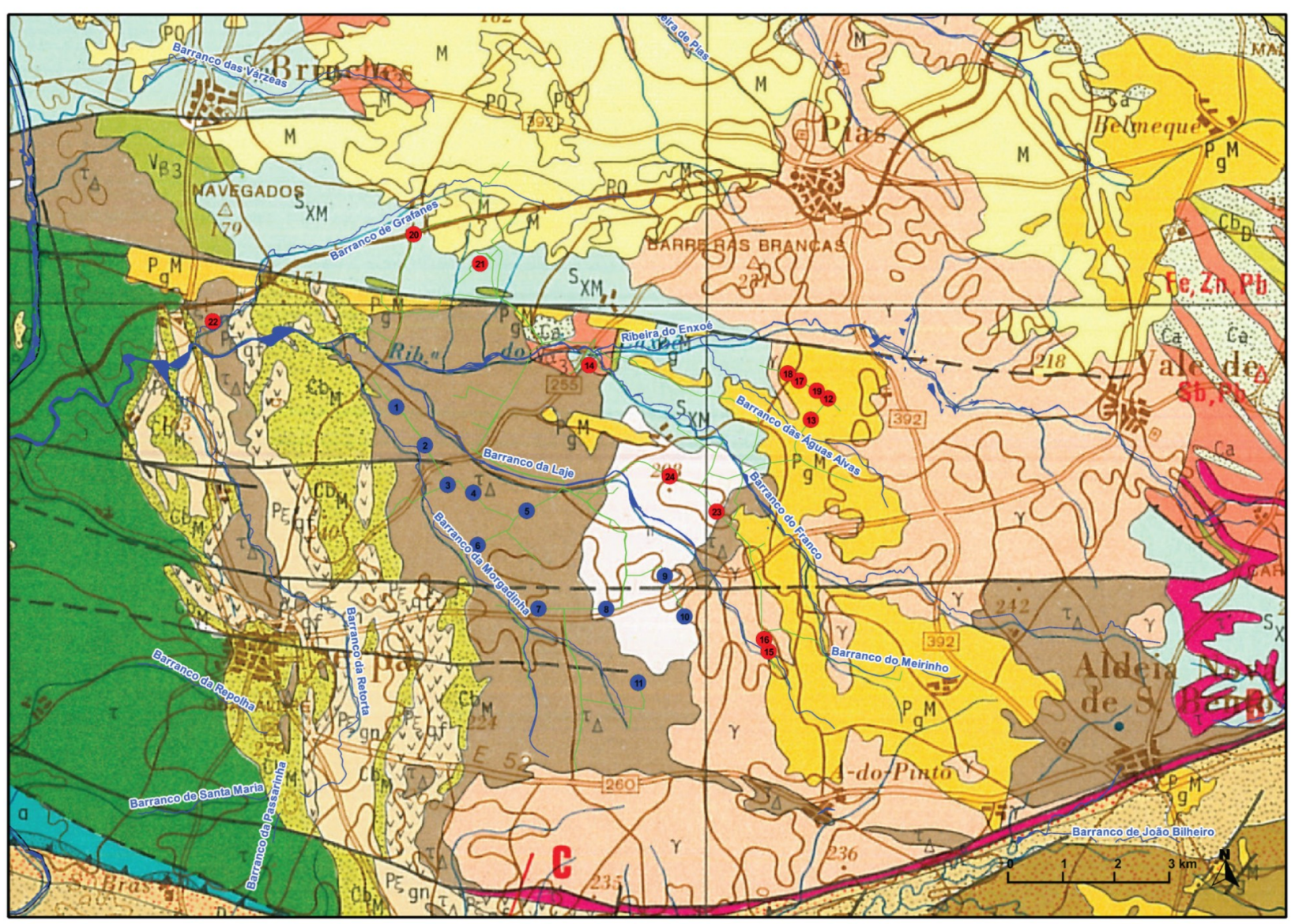

\begin{tabular}{|c|c|c|c|}
\hline \multicolumn{2}{|r|}{ MACIÇO DE BEJA' } & & \\
\hline$\gamma$ & Granitos & & \\
\hline$\pi$. & 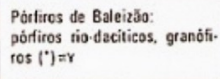 & - & Dioritos de Casa Branca \\
\hline is & $\begin{array}{l}\text { Complexo gabro-dioritico de } \\
\text { Cuba: gabros, dionitos, quartzo. } \\
\text { dioritos e granótiros quate }\end{array}$ & & $\begin{array}{l}\text { Gabros de Beja: gabros e anor- } \\
\text { tositos cunulados }\end{array}$ \\
\hline ED & $\begin{array}{l}\text { Dioritos de Monte Novo: } \\
\text { dicritos, granodicititos }\end{array}$ & & 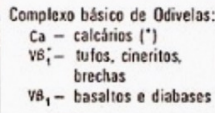 \\
\hline $\mathrm{HAC}_{\mathrm{AC}}$ & $\begin{array}{l}\text { Xistos de AllundJ̃o: } \\
\text { xisłos ardesiferos e xistos } \\
\text { grauvacoides }\end{array}$ & & 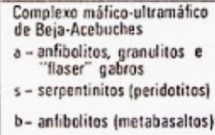 \\
\hline
\end{tabular}

Fig. 3. Localização dos sítios na Carta Geológica de Portugal, 1:2000000, fl.8; ver identificação dos sítios na legenda da imagem anterior.

Fig. 3. Location of the sites in the Carta Geológica de Portugal, 1:2000000, fl.8; see the identification of the sites in the previous figure.

\footnotetext{
${ }^{8} \mathrm{Na}$ análise das componentes artefactuais, designadamente de recipientes cerâmicos, tivemos em consideração as propostas tipológicas, e de enquadramento cronológico-cultural, de Schubart (1975), Soares \& Silva (1981, 1992), Soares (2014), Lago et al. (1998), Soares (2005, 2013), Mataloto \& Boaventura (2009), Mataloto et al. (2013) e Silva (2014).
} 


\subsection{Horta da Morgadinha}

Horta da Morgadinha localiza-se no topo de uma elevação de vertentes acentuadas. Nesta área, há uma confluência entre os Barrancos da Morgadinha e da Laje, que se acentua até desaguarem na Ribeira de Enxoé. Esta ocorrência patrimonial corresponde a um conjunto de estruturas em negativo identificadas num segmento de reta com cerca $850 \mathrm{~m}$ (Fig. 4). É um conjunto que apresenta uma variabilidade morfológica acentuada e com contextos que remetem para diferentes períodos da Préhistória Recente (BAPTISTA \& GOMES 2010a). Quando consideramos a sua distribuição espacial, é possível equacionar a existência de cinco áreas. Ve- jamos o conjunto de estruturas, e a sua inserção cronológica, que compõe cada área:

- Área 1 (Fig. 5). Conjunto de estruturas de planta subretangular, dispostas em linhas paralelas, com uma orientação NW-SE. Neste conjunto é possível reconhecer duas categorias de dimensão: uma categoria que corresponde a estruturas com um comprimento de $1 \mathrm{~m}$ e outra categoria onde se inserem estruturas com um comprimento 3 a $4 \mathrm{~m}$. Duas das estruturas deste conjunto encontravam-se cortadas por duas estruturas de planta de subcircular. A componente artefactual de uma delas enquadra-se na Idade do Bronze.

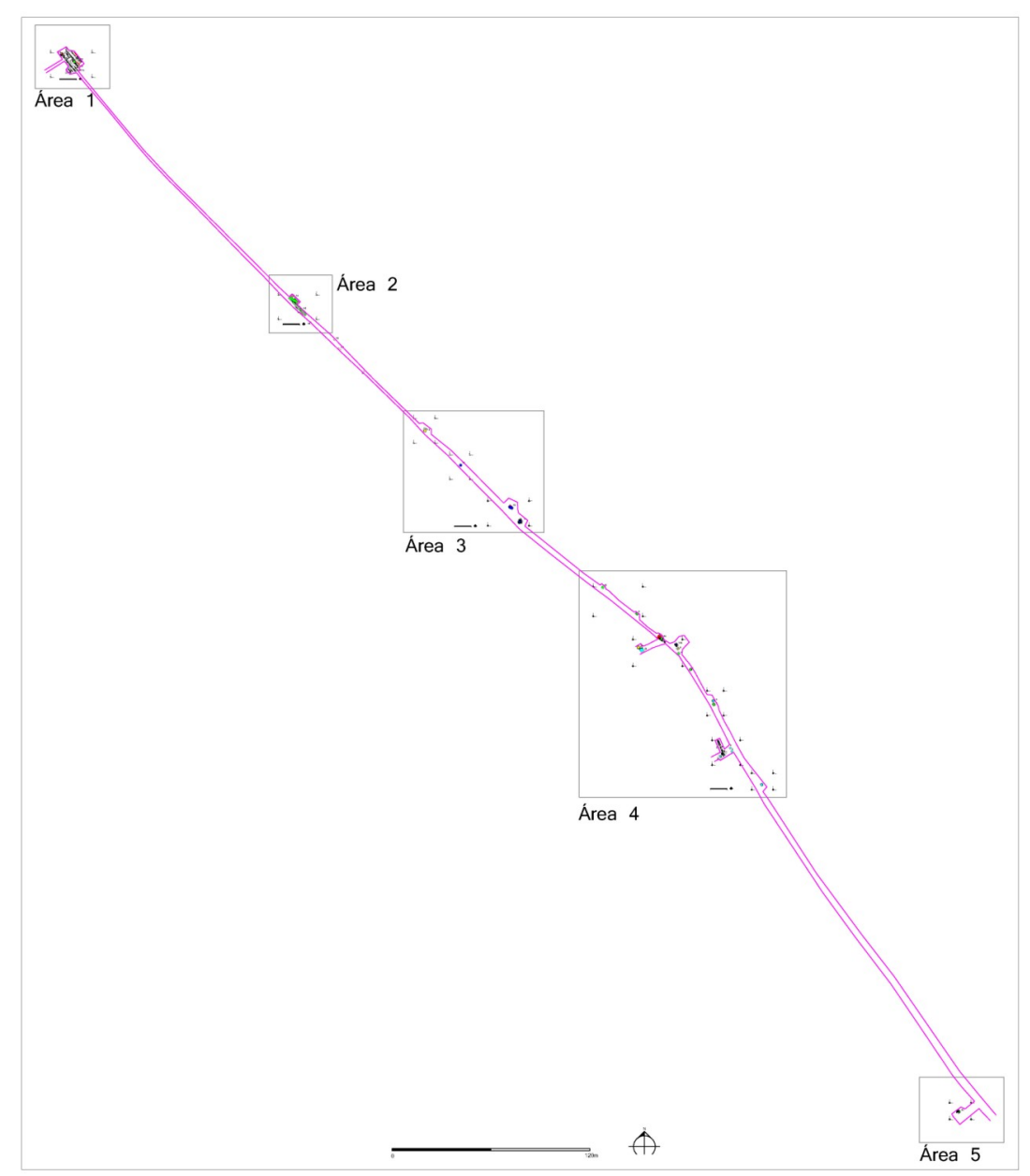

Fig. 4. Horta da Morgadinha, planta geral da intervenção. Linha púrpura: limites de afetação do projeto.

Fig. 4. Horta da Mordaginha, general plan of the interventation. Purple line: pipeline's project limits.

- Área 2 (Fig. 6). Conjunto de estruturas de planta subretangular (com $1 \mathrm{~m}$ de comprimento), disposta em linhas com orientação NW-SE; uma das estruturas apresentava-se perpendicular às linhas. A cortar este conjunto, foi identificado um hipogeu constituído por uma estrutura de acesso, um corredor, uma antecâmara e uma câmara, que se encontra- va selada por uma estrutura pétrea. Na câmara encontrava-se um nível de inumação de um indivíduo de idade adulta depositado numa orientação SE (crânio)-NW (pés), com o crânio sobre o lado esquerdo e o membro superior direito fletido para o lado esquerdo, repousando a mão junto à região do pescoço. Em associação à inumação foi identificado 

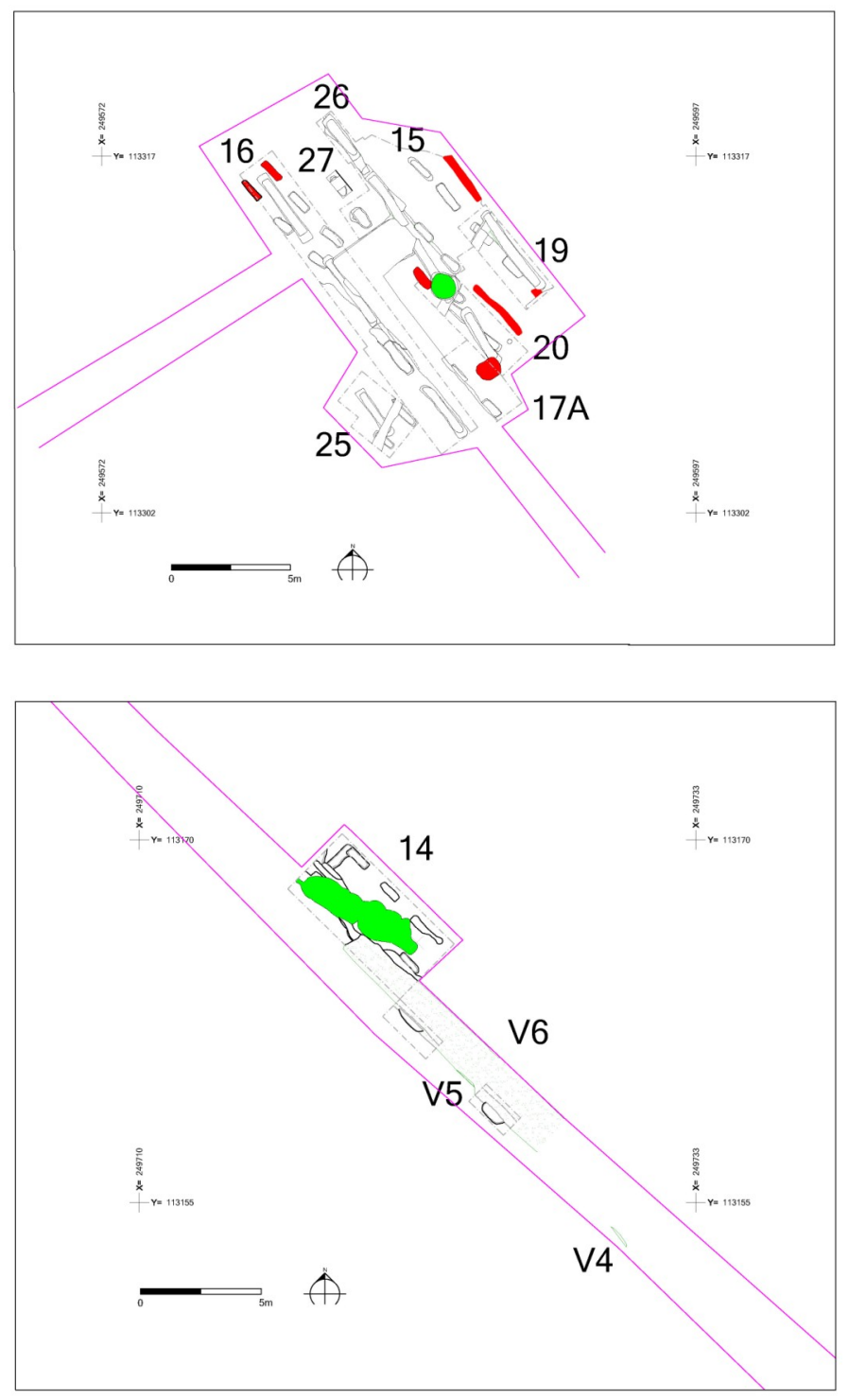

Fig. 5. Horta da Morgadinha, Área 1. Linha púrpura: limites de afetação do projeto; Verde: Idade do Bronze; Sem preenchimento: estrutura de planta subretangular (Pré-história Recente); Vermelho: contexto não escavado;

Fig. 5. Horta da Morgadinha, Area 1. Purple line: pipeline's project limits; No color: sub-rectangula plan structure (Late Prehistory); Green: Bronze Age; Red: non excavated feature. um recipiente de paredes retas e fundo esférico, com asa. Este contexto de inumação insere-se na Idade do Bronze regional. No lado SW desta área, regista-se a presença de estruturas de planta subretangular, que não foram intervencionadas.

- Área 3 (Fig. 7). Conjunto de quatro estruturas que ocorrem de modo esparso na área intervencionada. Em termos morfológicos, este conjunto comporta alguma variabilidade: a estrutura da Sondagem 11 apresenta uma forma tendencialmente cilíndrica; a estrutura da Sondagem 12 tem uma forma globular; na Sondagem 13, a estrutura apresenta uma planta subcircular muito irregular, sugerindo estar afetada por trabalhos de lavra recentes; e a estrutura da Sondagem 18 apresenta uma planta composta por dois módulos subcirculares articulados (um deles de pou- ca profundidade e o outro com mais de $1 \mathrm{~m}$ ). As estruturas das Sondagens 11, 12 e 18 apresentam uma componente artefactual articulável com o Neolítico Final/Calcolítico. A estrutura da Sondagem 13 não apresenta componente artefactual.

- Área 4 (Fig. 8). Conjunto de 15 estruturas de planta subcircular, um valado de perfil em $U$, orientado a NW (identificado nas Sondagens 22 e 23), e um conjunto de interfaces de planta subretangular' (Sondagem 24). Nesta área, as estruturas distribuemse de modo espaçado, formando, por vezes, concentrações de, no máximo, três estruturas. Um aspeto a salientar acerca das estruturas de planta subcircular é a variabilidade morfológica, registando-se que: seis das estruturas correspondem a formas abertas (de paredes retas), com uma profundidade até $0,5 \mathrm{~m}$;

\footnotetext{
${ }^{9}$ Não nos foi possível observar os limites deste conjunto de interfaces, podendo ser semelhantes aos identificados nas Áreas 1 e 2 , sendo de salientar que se encontravam cortados por uma estrutura de planta subcircular com uma componente artefactual pré-histórica.
} 

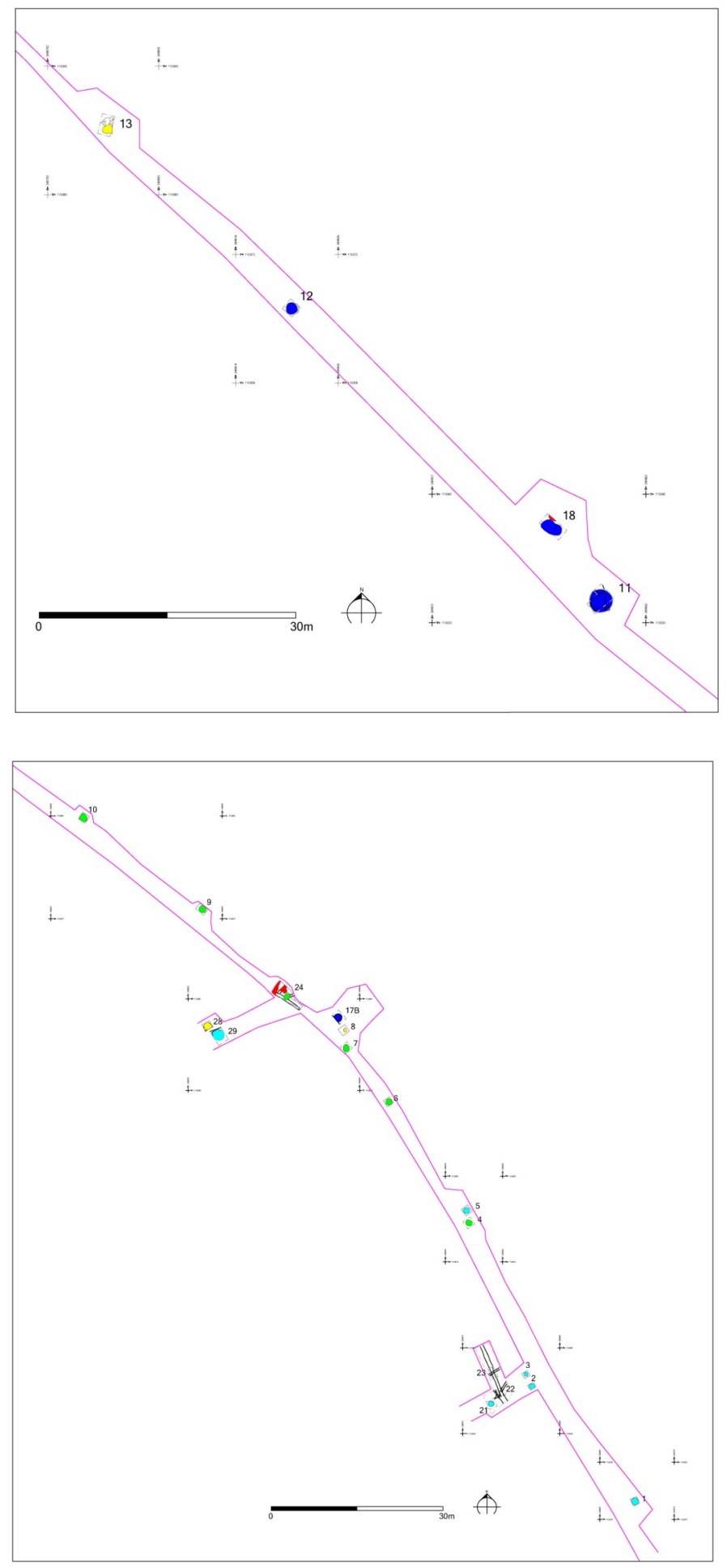

Fig. 7. Horta da Morgadinha, Área 3. Linha púrpura: limites de afetação do projeto; Amarelo: estrutura "vazia"; Azul escuro: Transição Neolítico Final/Calcolítico; Vermelho: contexto não escavado.

Fig. 7. Horta da Morgadinha, Area 3. Purple line: pipeline's project limits; Red: non excavated feature Yellow: "empty" structure; Dark blue: Late Neolithic/ Calcolithic transition; Red: non excavated feature. quatro estruturas correspondem a formas semiglobulares fechadas, com uma profundidade até $0,5 \mathrm{~m}$; quatro estruturas apresentam "perfil em saco", com uma profundidade entre $1,5 \mathrm{~m}$ e $2 \mathrm{~m}$; e duas estruturas apresentam paredes irregulares, de pouca profundidade. Nas estruturas das Sondagens 4, 6, 7, 9 e 10, a componente cerâmica é enquadrável na Idade do Bronze; e a estrutura da Sondagem 17 apresenta uma componente cerâmica calcolítica.
Fig. 8. Horta da Morgadinha, Área 4. Linha púrpura: limites de afetação do projeto; Amarelo: estrutura "vazia"; Azul claro: Pré-história Recente indeterminado; Azul escuro: Calcolítico; Verde: Idade do Bronze; Sem preenchimento: outros contextos; Vermelho: contexto não escavado.

Fig. 8. Horta da Morgadinha, Area 4. Purple line: pipeline's project limits; Red: non excavated feature; Yellow: "empty" structure; Light blue: Undetermined period of Late Prehistory; Dark blue: Calcolithic; Green: Bronze Age; No color: other features; Red: non excavated feature.

- Área 5 (Fig. 9). Uma estrutura de planta subcircular, cuja componente cerâmica é enquadrável no Calcolítico e um conjunto de quatro estruturas de planta subretangular que, embora sejam morfologicamente semelhantes às que ocorrem na Área 1, não apresentam relações estratigráficas que permitam a sua associação à Pré-história. Sendo de referir que existem vários paralelos que são interpretados como valas associadas a trabalhos agrícolas. 


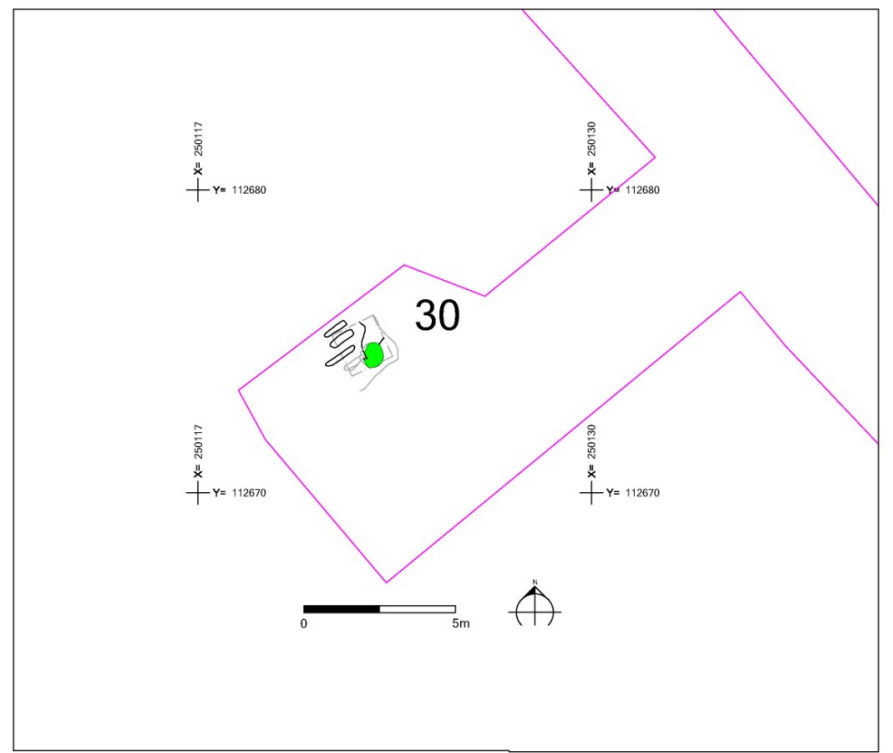

Fig. 9. Horta da Morgadinha, Área 5. Linha púrpura: limites de afetação do projeto; Verde: Idade do Bronze; Sem preenchimento: outros contextos. Fig. 9. Horta da Morgadinha, Area 5. Purple line: pipeline's project limits; Green: Bronze Age; No color: other features.
No que diz respeito às sequências de enchimento das estruturas, é de salientar que, grande parte apresentava um ou mais depósitos de matriz argilosa, nos quais se registava a ocorrência aleatória de fragmentos de recipientes cerâmicos e, por vezes, material lítico. Em alguns dos casos, estes depósitos argilosos eram intercalados por níveis de blocos pétreos, que tanto podiam ocorrer no topo, a meio ou na base da estrutura. Para além destas sequências de enchimento, há a salientar que em duas estruturas foram observados níveis intencionais de deposição: na estrutura da Sondagem 11, entre os blocos pétreos que compunham a base do enchimento da estrutura, encontrava-se um conjunto artefactual muito abundante e diversificado, onde se destaca a presença de partes de recipientes cerâmicos enquadráveis no Neolítico Final/Calcolítico (Fig. 10 e 11); na estrutura da Sondagem 30, a meio da estrutura, foi identificado um nível de inumação de um pequeno carnívoro, depositado no topo de um depósito argiloso, em posição de decúbito lateral direito, com o crânio para $\mathrm{N}$ e encostado à parede da estrutura; o depósito sobre o qual foi colocado o animal e o depósito que o cobria apresentava fragmentos de recipientes cerâmicos enquadráveis na Idade do Bronze (Fig. 12).

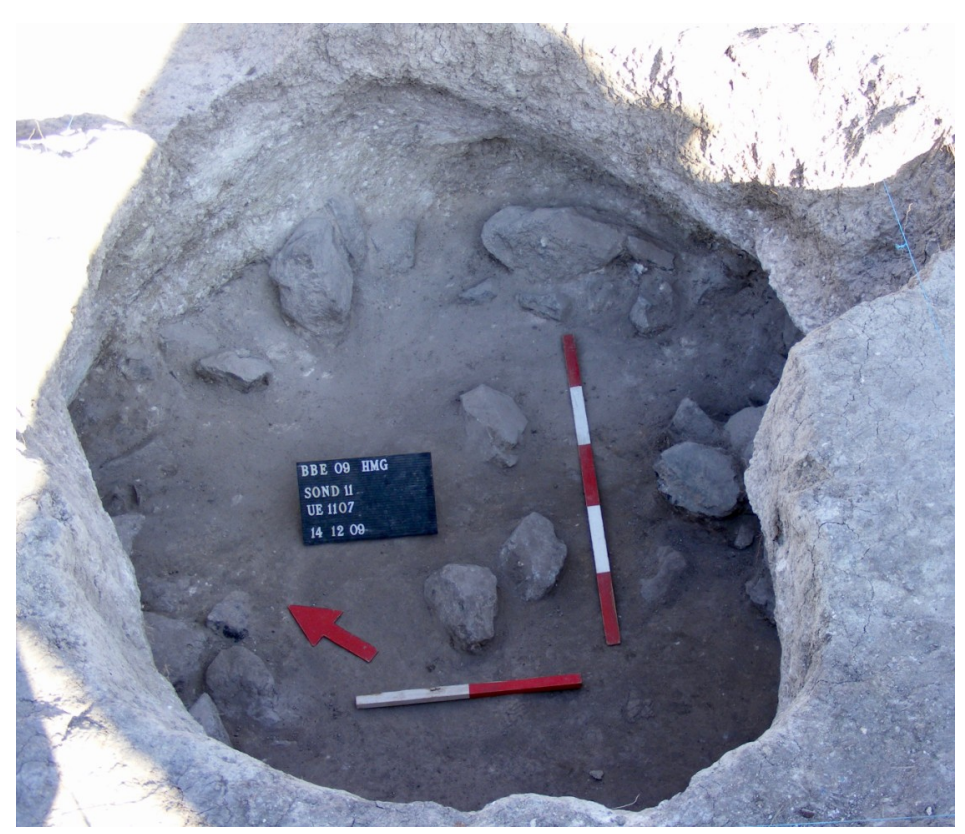

Fig. 10. Horta da Morgadinha, topo do depósito UE 1107: concentração de blocos pétreos, material cerâmico e outras categorias de artefactos.

Fig. 10. Horta da Morgadinha, top of the deposit UE 1107: concentration of stones, ceramic and other materials. 

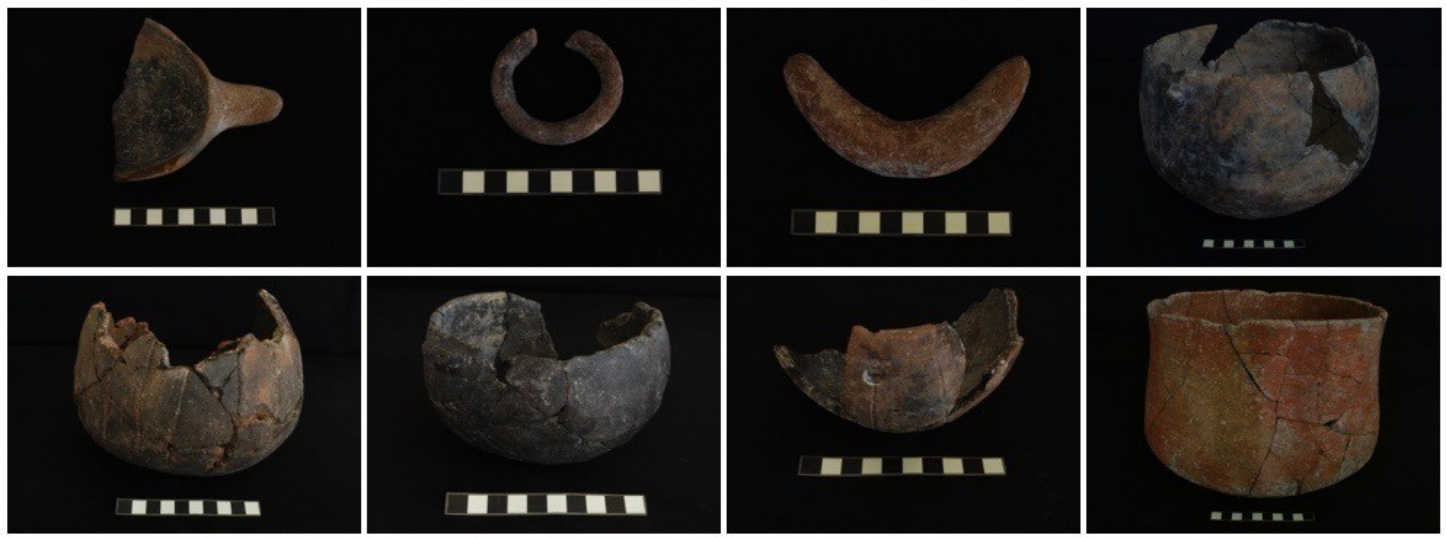

Fig. 11. Horta da Morgadinha, componente artefactual cerâmica dos depósitos da base da estrutura. Fig. 11. Horta da Morgadinha, ceramic elements from the bottom deposits of the structure.

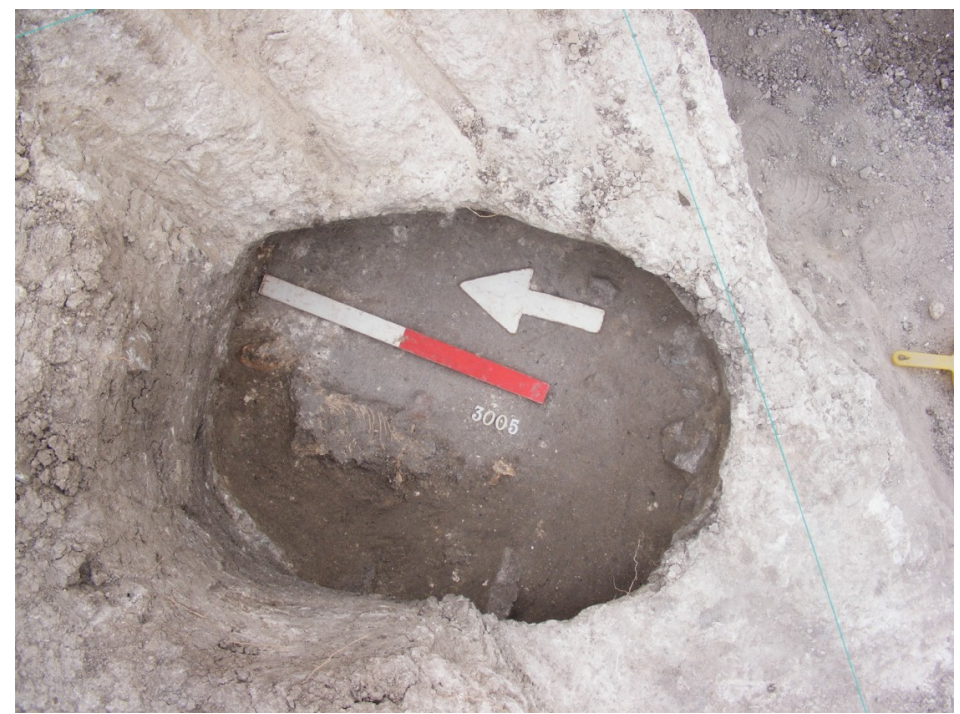

Fig. 12. Horta da Morgadinha, nível de inumação de cadáver animal. Fig. 12. Horta da Morgadinha, animal's burial context.

\subsection{Horta da Morgadinha 1}

Horta da Morgadinha 1 situa-se no sopé da colina onde estão localizadas Horta da Morgadinha, que acabamos de apresentar, e Horta da Morgadinha 2 , que será apresentada no próximo ponto. Os trabalhos de escavação (BAPTISTA et al. 2010) permitiram a identificação de três estruturas em negativo de características morfológicas semelhantes (Fig. 13): planta circular de base côncava, com um diâmetro de topo de cerca de $1 \mathrm{~m}$ e um diâmetro de base entre 0,7 e $0,8 \mathrm{~m}$; paredes regulares e ligeiramente divergentes, com uma profundidade entre 0,80 e 1,12 m. O seu enchimento é constituído por depósitos argilosos que apresentam variações de coloração e compactação e por níveis, ou aglomerados, de pedras de pequena dimensão. A componente artefactual é constituída por fragmentos de recipientes cerâmicos e fragmentos de elementos de moagem; na estrutura da Sondagem 1, foi também recolhido um conjunto de vestígios arqueofaunísticos (fauna mamalógica).

\subsection{Horta da Morgadinha 2}

A intervenção em Horta da Morgadinha 2 (CHAVES et al. 2012) desenvolveu-se no topo aplanado de uma colina ladeada pelos Barrancos da Morgadinha e da Laje. Para esta zona, estava projetada a interseção de duas valas de implantação de condutas, uma com orientação SW-NE e outra orientada a NW (Figura 14). Na vala de obra orientada a NW, foram identificadas três estruturas em negativo, cuja distribuição espacial permite delimitar uma área (a Área 1, Fig. 15) caracterizada pela ocorrência pontual de estruturas. Nesta área, uma das estruturas apresentava uma componente cerâmica articulável com o Neolítico Final/Calcolítico, as outras duas não apresentavam qualquer elemento de natureza artefactual. Na zona de interseção das duas valas, podemos considerar a existência de mais duas áreas:

- A Área 2 (Fig. 16), na qual foi identificado o troço de um fosso, cuja planta não foi possível 


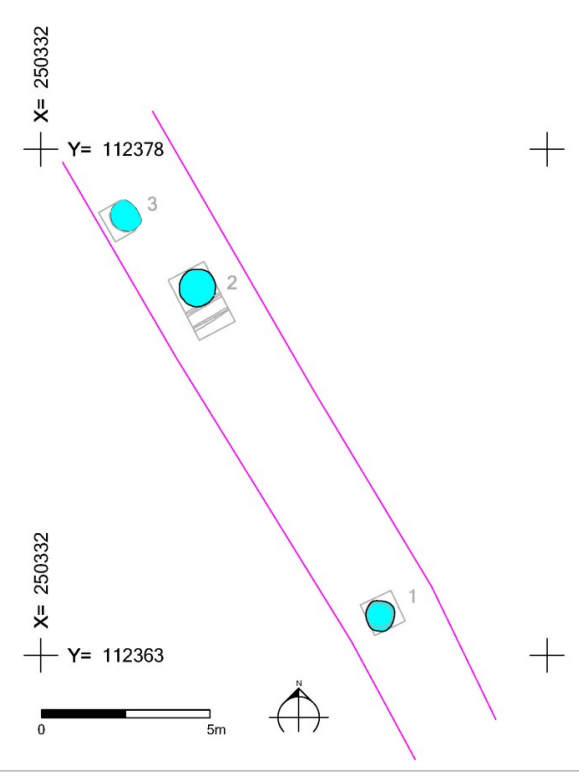

Fig. 13. Horta da Morgadinha 1, planta geral da intervenção. Linha púrpura: limites de afetação do projeto; Azul claro: Pré-história Recente indeterminado; Sem preenchimento: outros contextos.

Fig. 13. Horta da Morgadinha 1, general plant of the interventation. Purple line: pipeline's project limits; Light blue: Undetermined period of Late Prehistory; No color: other features.

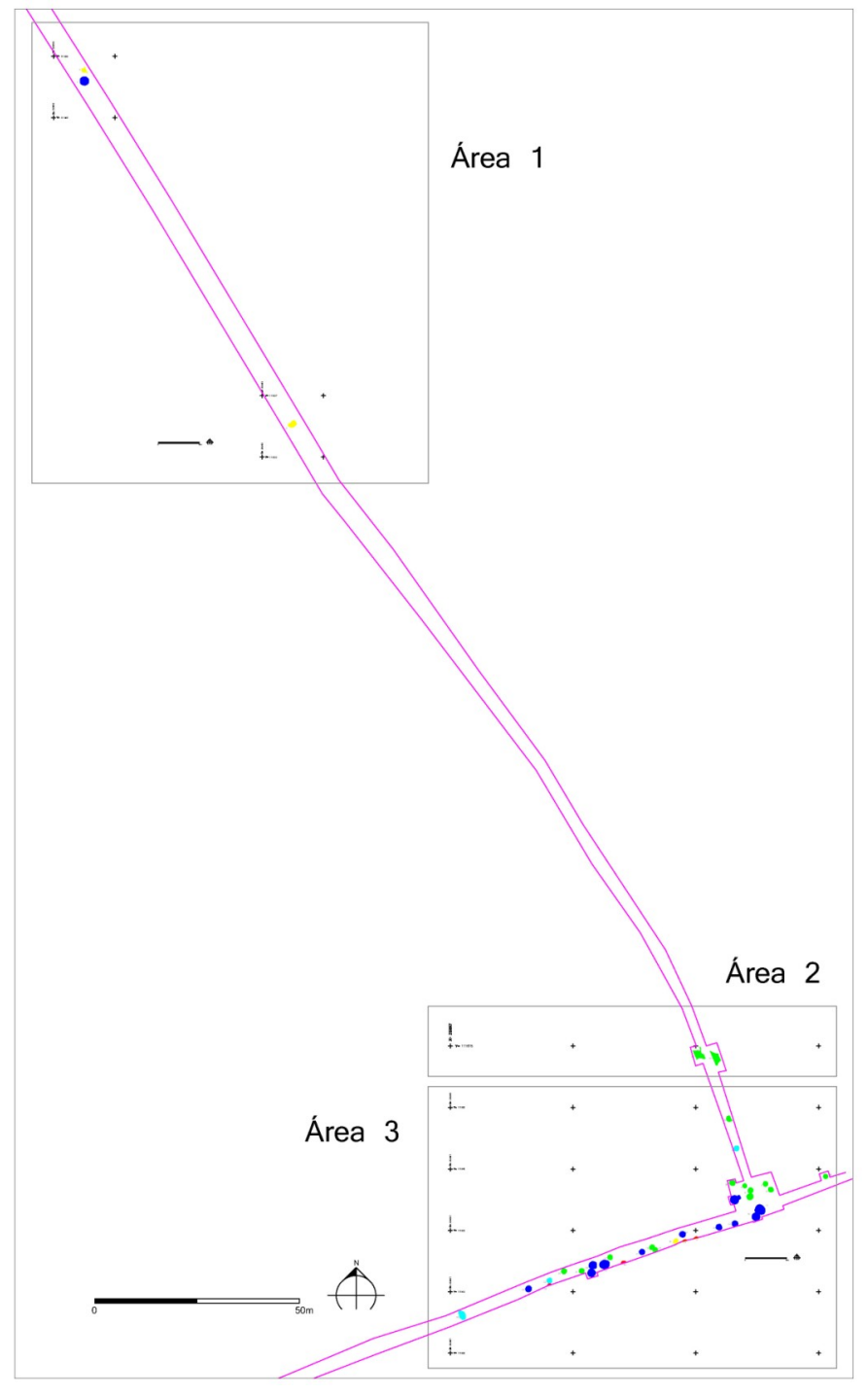

Fig. 14. Horta da Morgadinha 2, planta geral da intervenção. Linha púrpura: limites de afetação do projeto.

Fig. 14. Horta da Morgadinha 2, general plant of the interventation. Purple line: pipeline's project limits. 


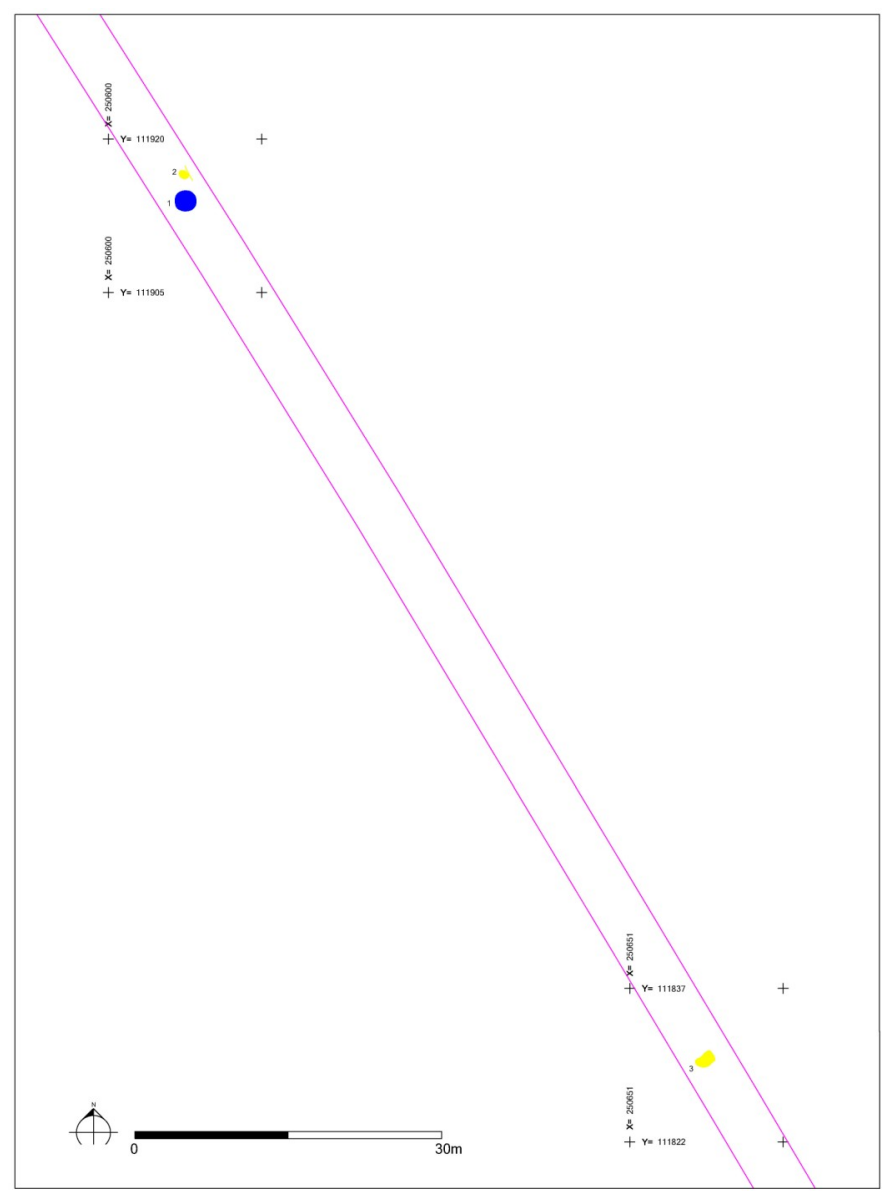

Fig. 15. Horta da Morgadinha 2, Área 1. Linha púrpura: limites de afetação do projeto; Amarelo: estrutura "vazia"; Azul escuro: Transição Neolítico Final/Calcolítico.

Fig. 15. Horta da Morgadinha 2, Area 1. Purple line: pipeline's project limits; Red: non excavated feature Yellow: "empty" structure; Dark blue: Late Neolithic Calcolithic transition.

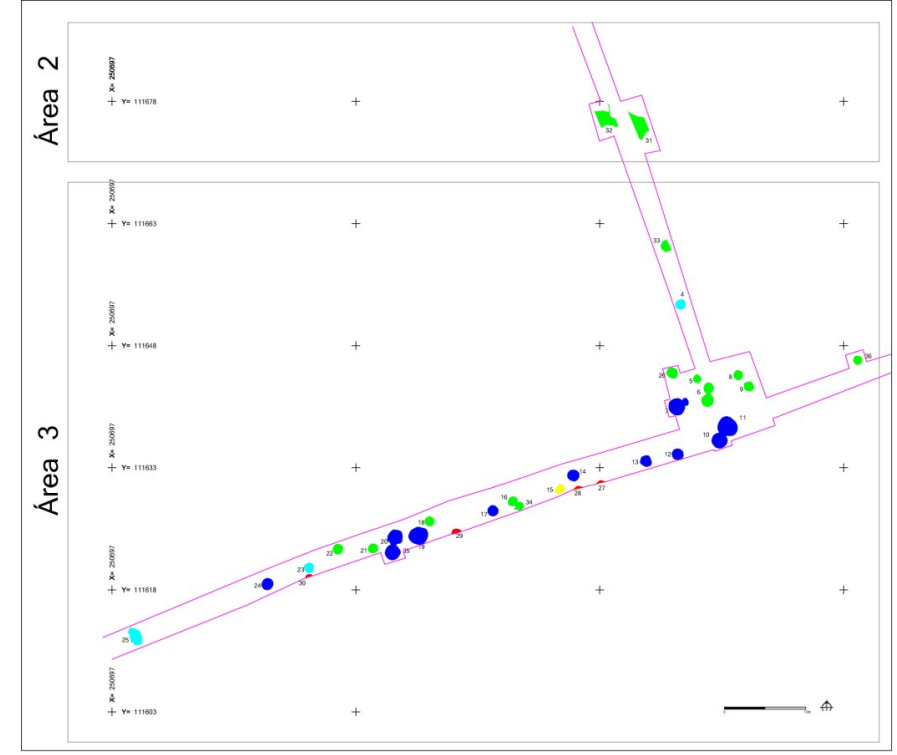

Fig. 16. Horta da Morgadinha 2, Áreas 2 e 3. Linha púrpura: limites de afetação do projeto; Amarelo: estrutura "vazia"; Azul claro: Pré-história Recente indeterminado; Azul escuro: Transição Neolítico Final/Calcolítico; Verde: Idade do Bronze; Vermelho: contexto não escavado.

Fig. 16. Horta da Morgadinha 2, Areas 2 and 3. Purple line: pipeline's project limits; Yellow: "empty" structure; Light blue: Undetermined period of Late Prehistory; Dark blue: Late Neolithic/Calcolithic transition; Green: Bronze Age; Red: non excavated feature.

observar por exceder a vala de implantação da conduta. A componente cerâmica associada ao seu enchimento enquadra-se na Idade do Bronze ${ }^{10}$.

\section{- A Área 3 (Fig. 16) corresponde um espaço}

onde prolifera um conjunto de 27 estruturas, algumas das quais não foram intervencionadas por se localizarem fora da área de implantação da conduta. Este conjunto é constituído por estruturas de morfologia distinta: formas simples de tendência semiglobular

\footnotetext{
${ }^{10} \mathrm{Na}$ componente cerâmica é de destacar a presença de taças carenadas idênticas às que ocorrem em Casarão da Mesquita (Santos et al. 2008) e Arroteia (Porfírio \& Serra 2012).
} 
(nove estruturas), formas semiglobulares muito irregulares (cinco estruturas), formas simples de tendência semicilíndrica (cinco estruturas), formas compósitas de planta em forma de 8 (quatro estruturas) e uma estrutura de corpo cilíndrico com nichos parietais. Os conjuntos artefactuais provenientes destas estruturas permitem a sua articulação com diferentes períodos: em onze casos, a componente cerâmica e metálica é enquadrável na Idade do Bronze; em nove estruturas, a componente cerâmica remete para o Neolítico Final/Calcolítico; e, nos restantes casos, o conjunto artefactual não permite a sua associação a um período específico no âmbito da Pré-história Regional. Considerando a inserção cronológica, é de salientar que a maioria das estruturas da Idade do Bronze se encontra localizada na conduta que se desenvolve para NW e que as estruturas do Neolítico Final/Calcolítico se encontravam na conduta orientada a NE.

Algumas das sequências de enchimento das estruturas apresentam um elevado grau de formalização, apresentando níveis de deposição em articulação com níveis pétreos e depósitos de colmatação. Vejamos alguns exemplos:

- A estrutura da Sondagem N. ${ }^{\circ} 7$ apresentava dois níveis de inumação de indivíduos subadultos: um deles (6-7 anos) foi depositado em decúbito lateral direito com membros superiores e inferiores fleti- dos, com orientação W(crânio)-E(pés), num eventual nicho, localizado na parte superior da estrutura, que se encontrava colmatado por uma estrutura pétrea; o outro (12 anos) foi depositado num nicho parietal também localizado na parte superior da estrutura e também colmatado por uma estrutura pétrea; foi depositado em decúbito lateral esquerdo, com membros fletidos, com orientação SE(crânio)-NW(pés) (Fig. 17). No corpo central da estrutura, os depósitos de enchimento da base apresentavam níveis pétreos aos quais se associava um conjunto artefactual constituído por: um recipiente cerâmico de paredes retas, fragmentos de diferentes recipientes cerâmicos, indústria lítica e vestígios arqueofaunísticos (ver GOMES et al. 2013). A componente cerâmica da estrutura permite a sua associação ao Neolítico Final/ Calcolítico.

- Nas estruturas das Sondagens 19 e 20/35, foram identificados níveis de deposição/inumação de elementos faunísticos. Na Sondagem 20/35, a estrutura apresentava um nível de inumação de um canídeo (Fig. 18). Este nível ocorre quase no topo do enchimento da estrutura, numa zona em que as paredes são muito inclinadas, encontrando-se o cadáver encostado à parede $\mathrm{E}$ da estrutura e apoiado sobre um nível pétreo; foi depositado em decúbito lateral esquerdo, estando o crânio, para $\mathrm{SE}$, e os coxais, para NE,
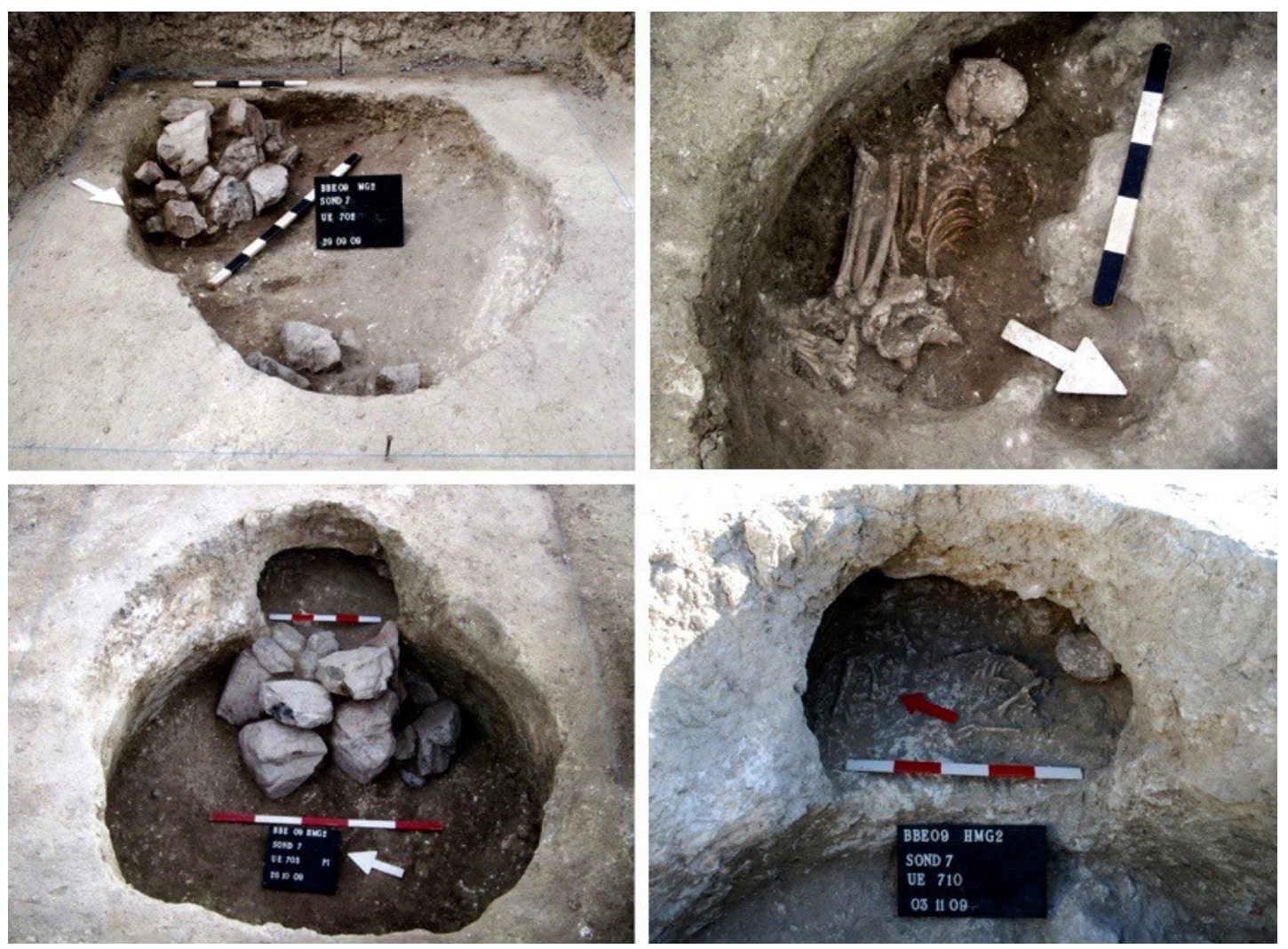

Fig. 17. Horta da Morgadinha 2: níveis de inumação e estruturas pétreas de condenação.

Fig. 17. Horta da Morgadinha 2: burial contexts and stone structures closing them. 


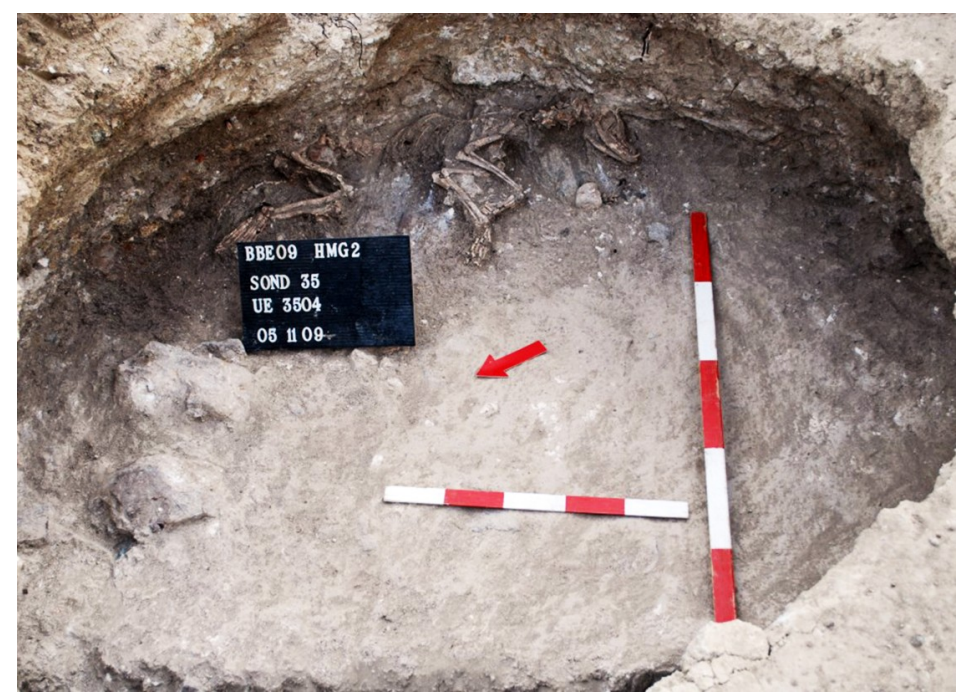

Fig. 18. Horta da Morgadinha 2: nível de inumação de um cadáver animal.

Fig. 18. Horta da Morgadinha2: animal's burial level.

apoiados em blocos do nível pétreo. A estrutura da Sondagem 19 apresentava, quase na base da estrutura, um nível constituído por dois cadáveres quase inteiros de canídeos, o crânio de um outro canídeo e duas concentrações de fauna (Fig. 19 e 20): uma localizada no centro da estrutura, constituída maioritariamente por ovicaprídeos; e outra, articulada com um nível pétreo encostado à parede $\mathrm{N}$ da estrutura, que apresenta conexões anatómicas de partes de canídeos e ainda um membro posterior de bovídeo. Neste nível, ocorre também fauna malacológica (uma concha Pecten Maximus), fragmentos de diferentes recipientes cerâmicos, pequeno recipiente inteiro e uma colher inteira (ver também GoMEs et al. ibid.). De um ponto de vista cronológico, estes contextos apresentam conjuntos artefactuais enquadráveis no Neolítico Final/Calcolítico.
- A estrutura da Sondagem 14 apresentava um depósito arqueofaunístico localizado quase no topo da estrutura (Fig. 21). Este nível encontrava-se sobreposto a uma sequência de enchimento constituída, fundamentalmente, por blocos pétreos, entre os quais se registava a presença de fragmentos cerâmicos (enquadráveis no Neolítico Final/Calcolítico).

- Na estrutura das sondagens 10/11, ao nível da base de um dos módulos que compõe a estrutura, foi identificado um nível pétreo onde se encontravam depositados recipientes cerâmicos inteiros, fragmentos que constituíam partes de recipientes e fragmentos que não permitem remontagem (Fig. 22 e 23). A análise destes elementos permite o seu enquadramento no Neolítico Final/Calcolítico.

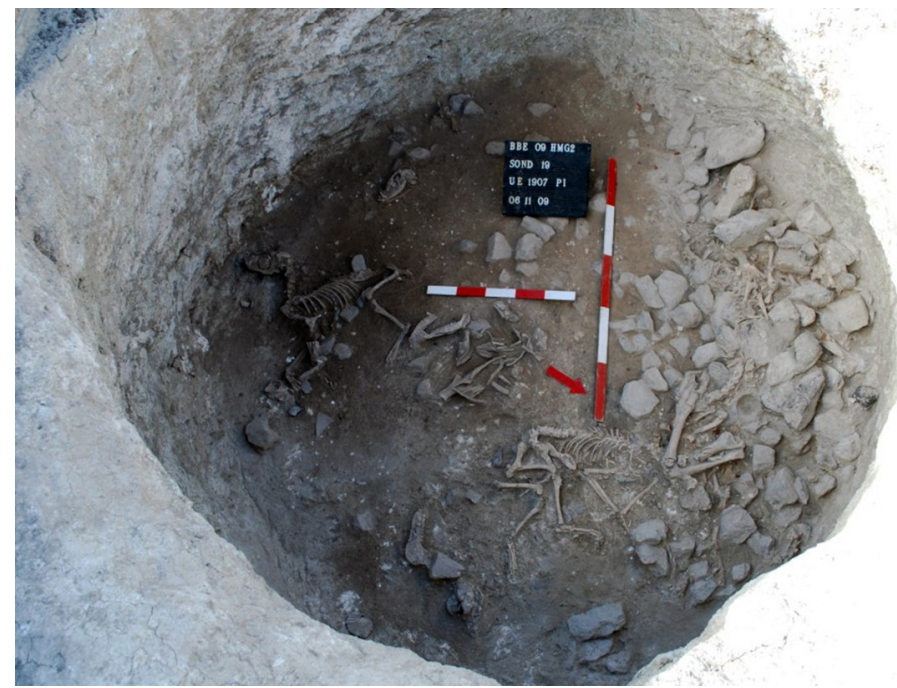

Fig. 19. Horta da Morgadinha 2: nível de inumação de cadáveres animais (canídeos) e de outros vestígios arqueofaunísticos.

Fig. 19. Horta da Morgadinha 2: dog's burial context and other archaeofaunistic remains. 


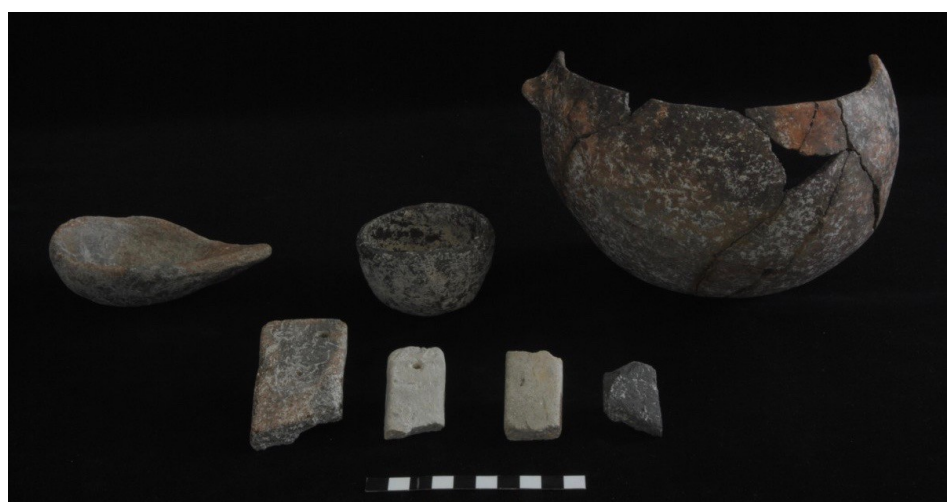

Fig. 20. Horta da Morgadinha 2: componente cerâmica associada ao contexto apresentado na figura anterior.

Fig. 20. Horta da Morgadinha 2: ceramic artefacts associated to the context presented in the previous figure.

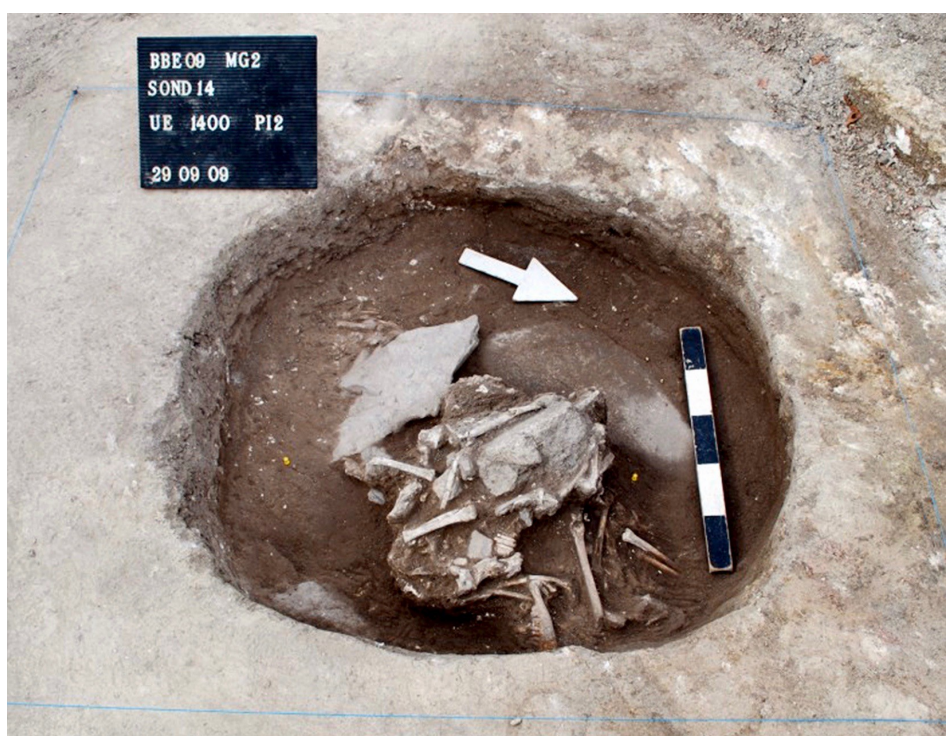

Fig. 21. Horta da Morgadinha 2: depósito arqueofaunístico.

Fig. 21. Horta da Morgadinha 2: deposit of archaeofaunistic elements.

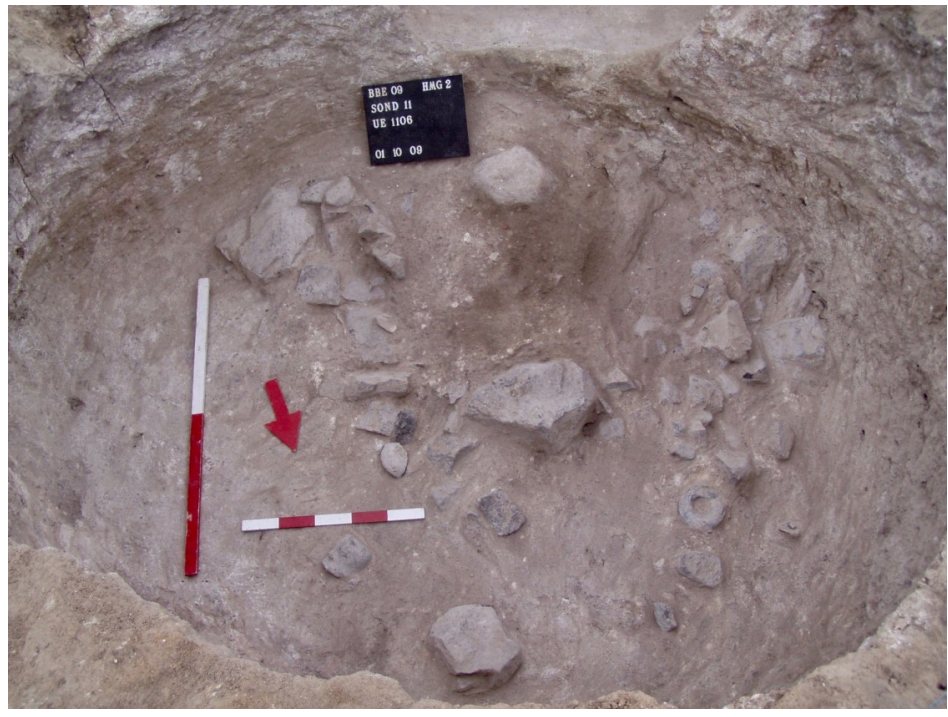

Fig. 22. Horta da Morgadinha 2: nível de deposição de elementos cerâmicos. Fig. 22. Horta da Morgadinha 2: deposition of ceramic elements. 


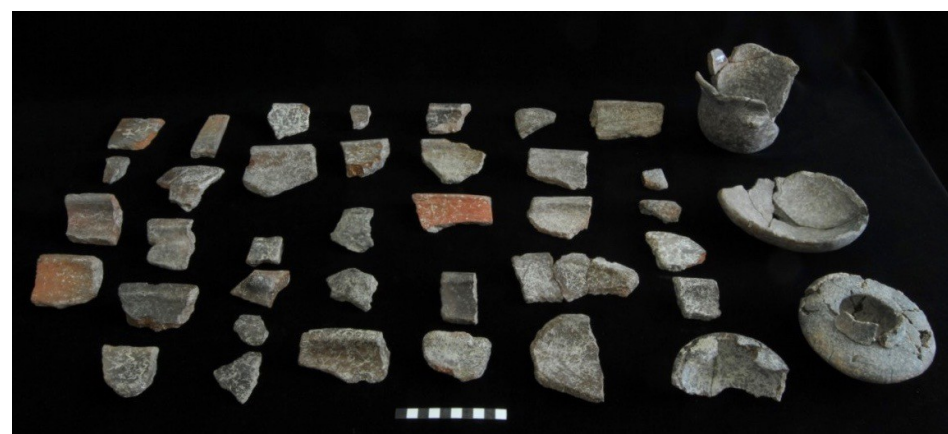

Fig. 23. Horta da Morgadinha 2: componente cerâmica do nível de deposição apresentado na figura anterior.

Fig. 23. Horta da Morgadinha 2: ceramic elements from the context presented in the previous figure.

- Na Sondagem 36, a estrutura apresentava ao nível da base uma concentração de 65 fragmentos cerâmicos (Fig. 24 e 25). A remontagem destes fragmentos permitiu constatar a presença de diferentes recipientes cerâmicos, enquadráveis na Idade do Bronze. Uma das remontagens remete para uma parte de um recipiente troncocónico invertido (fragmentos 1 a 38 e a sua associação aos fragmentos 39 e 40). Outro dos recipientes apresenta uma morfologia ovoide fechada, estando representado pela colagem entre os fragmentos 42 a 51 e a sua associação ao fragmento 41 . Os fragmentos 52 a 54 e os fragmentos 55 e 56 remontam entre si, mas não permitem a sua associação aos recipientes identificados nem aferir a morfologia do recipiente da qual faziam parte.

Para além destes níveis, identificados em campo por apresentarem um grau de formalização que chama a atenção no decurso da escavação, em gabinete foi possível reconhecer que, nas outras estruturas, muitos dos fragmentos cerâmicos, que ocorriam de modo aparentemente aleatório nos depósitos de enchimento, permitem remontagens. Neste exercício de remontagem, verifica-se a presença de recipientes quase inteiros ou de partes de recipientes. Tal constatação alerta-nos para a possibilidade de, nalguns casos, as práticas dos enchimentos das estruturas contemplarem modos de incorporação de fragmentos cerâmicos que, de um ponto de vista da sua expressão material no registo arqueológico, não apresentem a relevância dos níveis que acabamos de apresentar. A título de exemplo, refira-se o fosso da Área 2, cujo topo do enchimento apresentava um nível pétreo e sobre o qual os depósitos embalavam fragmentos cerâmicos que permitiram a reconstituição de diferentes recipientes cerâmicos, com diferentes graus de integridade (Fig. 26 e 27). Nas estruturas das Sondagens 6 e 8 , registou-se também um elevado número de remontagens entre fragmentos, cuja ocorrência, algo aleatória, não permitia adivinhar uma prática de transformação de recipientes em fragmentos e a sua congregação numa mesma estrutura.

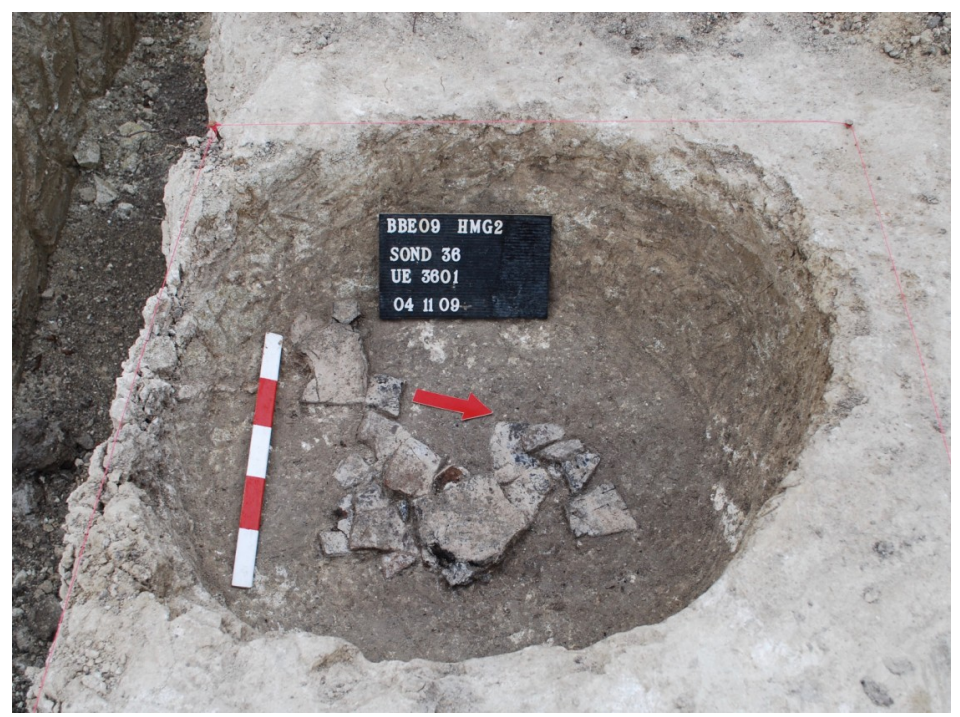

Fig. 24. Horta da Morgadinha 2: nível de deposição de fragmentos cerâmicos. Fig. 24. Horta da Morgadinha 2: deposition of ceramics fragments. 


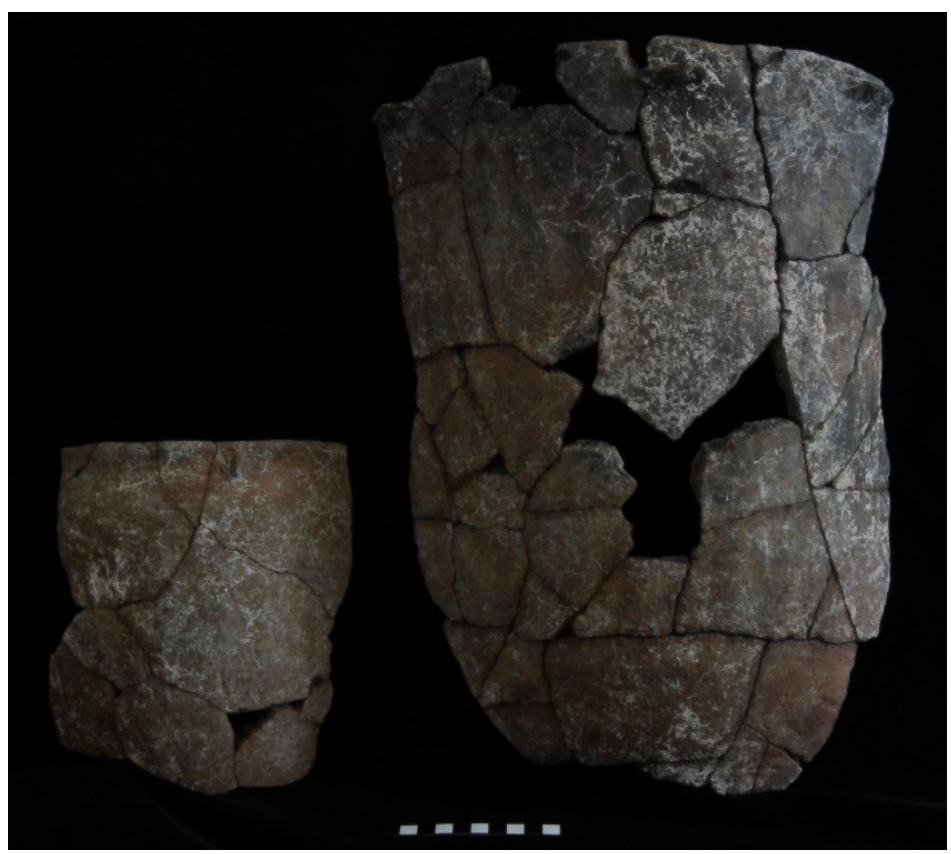

Fig. 25. Horta da Morgadinha 2: elementos cerâmicos (após remontagem) do contexto apresentado na figura anterior.

Fig. 25. Horta da Morgadinha 2: ceramic elements (after refitting) from the context presented in the previous figure.

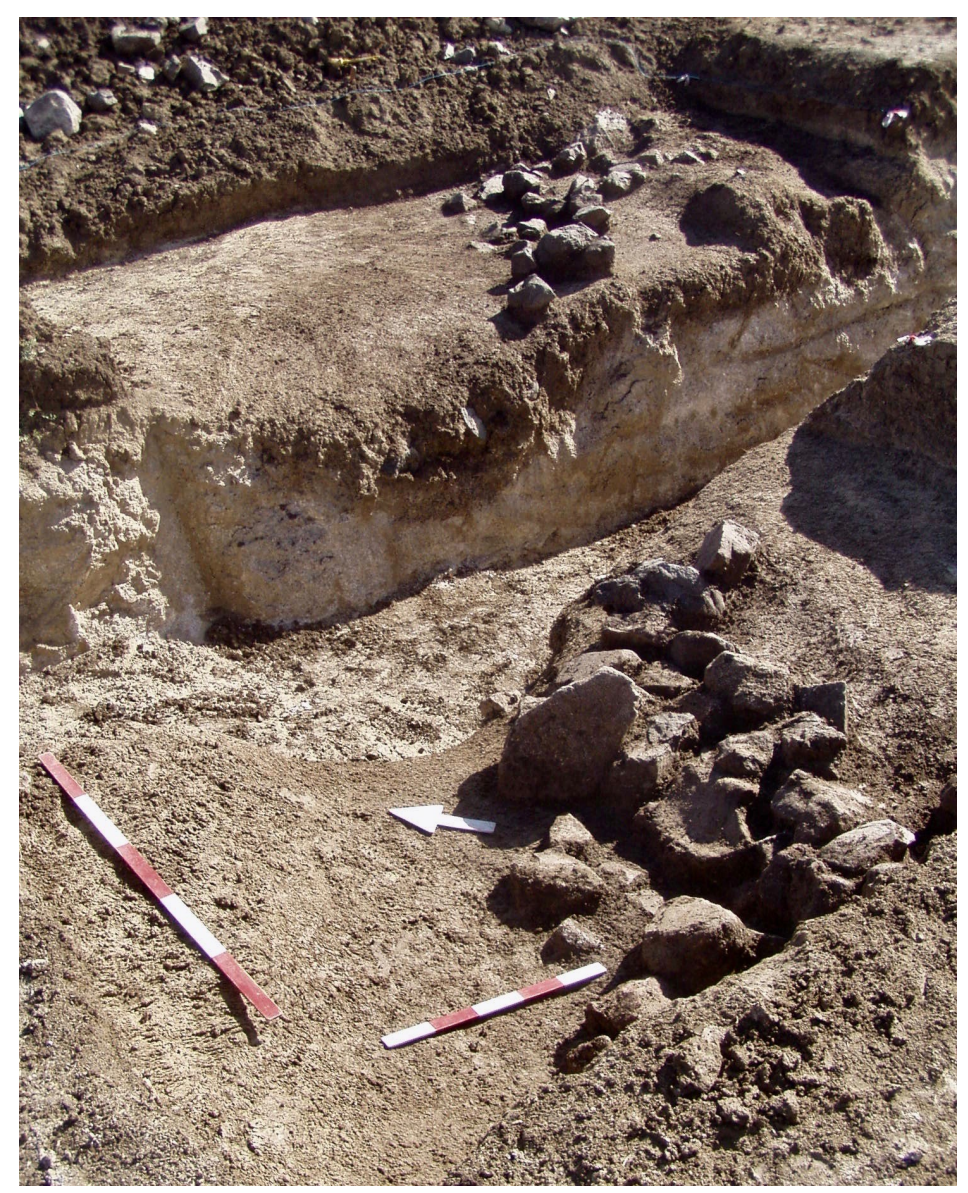

Fig. 26. Horta da Morgadinha 2: topo do enchimento do fosso.

Fig. 26. Horta da Morgadinha 2: top of the ditch's fill. 


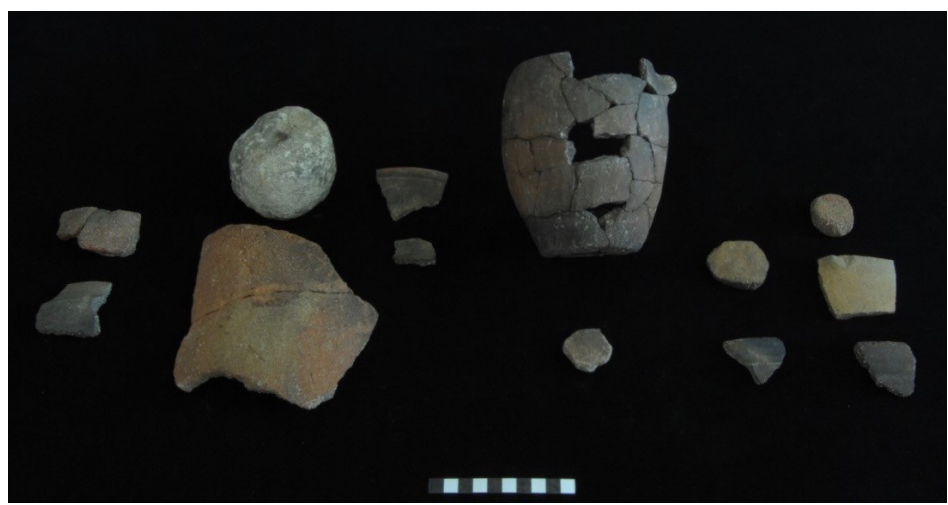

Fig. 27. Horta da Morgadinha 2: componente cerâmica dos depósitos de enchimento do fosso apresentado na imagem anterior.

Fig. 27. Horta da Morgadinha 2: ceramic elements from the ditch's fills.

\subsection{Espicharrabo 4}

Espicharrabo 4 (BAPTISTA \& GOMES 2010b) localiza-se a cerca de $0,5 \mathrm{Km}$ para NE de Horta da Morgadinha 2. A intervenção permitiu a identificação de contextos que remetem para uma longa diacronia de ocupação desta área, apresentando vestígios de cronologia pré-histórica, romana e islâmica. A ocupação pré-histórica (Fig. 28) é sugerida pela presença de fragmentos cerâmicos, que ocorrem no enchimento de duas estruturas em negativo: uma estrutura de planta subcircular (cerca de $0,5 \mathrm{~m}$ de diâmetro), paredes retas (cerca de $2 \mathrm{~m}$ de profundidade) e fundo plano, com um único depósito de enchimento; e uma estrutura de planta em forma de 8, isto é, composta por dois módulos de planta subcircular, com um único depósito de enchimento.

\subsection{Alcaria 4}

Em Alcaria 4 (CUNHA et al. 2010a) foram identificadas duas estruturas em negativo: a estrutura 1 apresenta uma planta subcircular (diâmetro de boca $0,5 \mathrm{~m}$ ), paredes retas (profundidade $0,7 \mathrm{~m}$ ) e fundo irregular; a estrutura 2 apresenta uma planta subcircular (diâmetro de boca 0,7 m), paredes retas (profundidade 0, $8 \mathrm{~m}$ ) e fundo plano (Fig. 29). Estas estruturas ocorrem numa área aplanada, que corresponde ao topo da elevação circundada pelos Barrancos da Laje e da Morgadinha. As estruturas apresentavam um único depósito de enchimento, de matriz argilosa, sem qualquer elemento de natureza artefactual. Refira-se que a inserção destes vestígios no âmbito da unidade de estudo é feita pela sua proximidade com outros vestígios pré-históricos (Horta da Morgadinha 2 e Espicharrabaro 4). Com efeito, no decurso da escavação não foi identificado qualquer elemento que remeta, de modo inequívoco, para a sua articulação com a cronologia em análise. Porém, considerando os inúmeros exemplos em que estruturas vazias ocorrem ao lado de estruturas de cronologia pré-histórica, é provável que as estruturas identificadas tenham uma relação espacial semelhante.
Assim, tendo em conta tal possibilidade, optou-se por considerar Alcaria 4 na unidade de estudo.

\subsection{Alcaria 5}

Alcaria 5 (CUNHA et al. 2010b) corresponde a um conjunto de duas estruturas localizadas a cerca de 1,5 km para SW de Alcaria 4, numa zona de vertente virada ao Barranco da Morgadinha. A estrutura 1 apresentava uma planta de forma semiglobular, com um diâmetro de boca de $0,95 \mathrm{~m}$ e $1,20 \mathrm{~m}$ de profundidade. No seu enchimento foram identificados dois depósitos de matriz argilosa compactos de cor castanha. O depósito da base apresentava, ao nível de topo, a inclusão de pedras de pequenas dimensões, e embalava fragmentos cerâmicos, enquadráveis no âmbito da Pré-história Recente regional, mas sem apresentar qualquer característica que permita a sua associação a um período específico. A estrutura 2 desenvolvia-se para lá da área intervencionada; pelo que foi possível observar, parece corresponder a uma estrutura de planta subcircular com cerca de $1,5 \mathrm{~m}$ de profundidade; continha um único depósito, sem componente artefactual associada (Fig. 30).

\subsection{Cidade das Rosas 4}

Cidade das Rosas 4 (CUNHA et al. 2010c) localiza-se na vertente virada ao Barranco da Morgadinha. A intervenção arqueológica permitiu a identificação das seguintes estruturas em negativo (Fig. 31):

- Uma possível estrutura em negativo que, localizada numa área que não viria a ser afetada pelo projeto, não foi intervencionada (Sondagem 1);

- Uma estrutura em negativo de planta irregular (Sondagem 2), com um único depósito de enchimento, no qual se encontravam embalados vestígios arqueofaunísticos (fauna mamalógica) e um conjunto de 108 fragmentos de recipientes cerâmicos, no qual a presença de ornatos brunidos permite a sua 

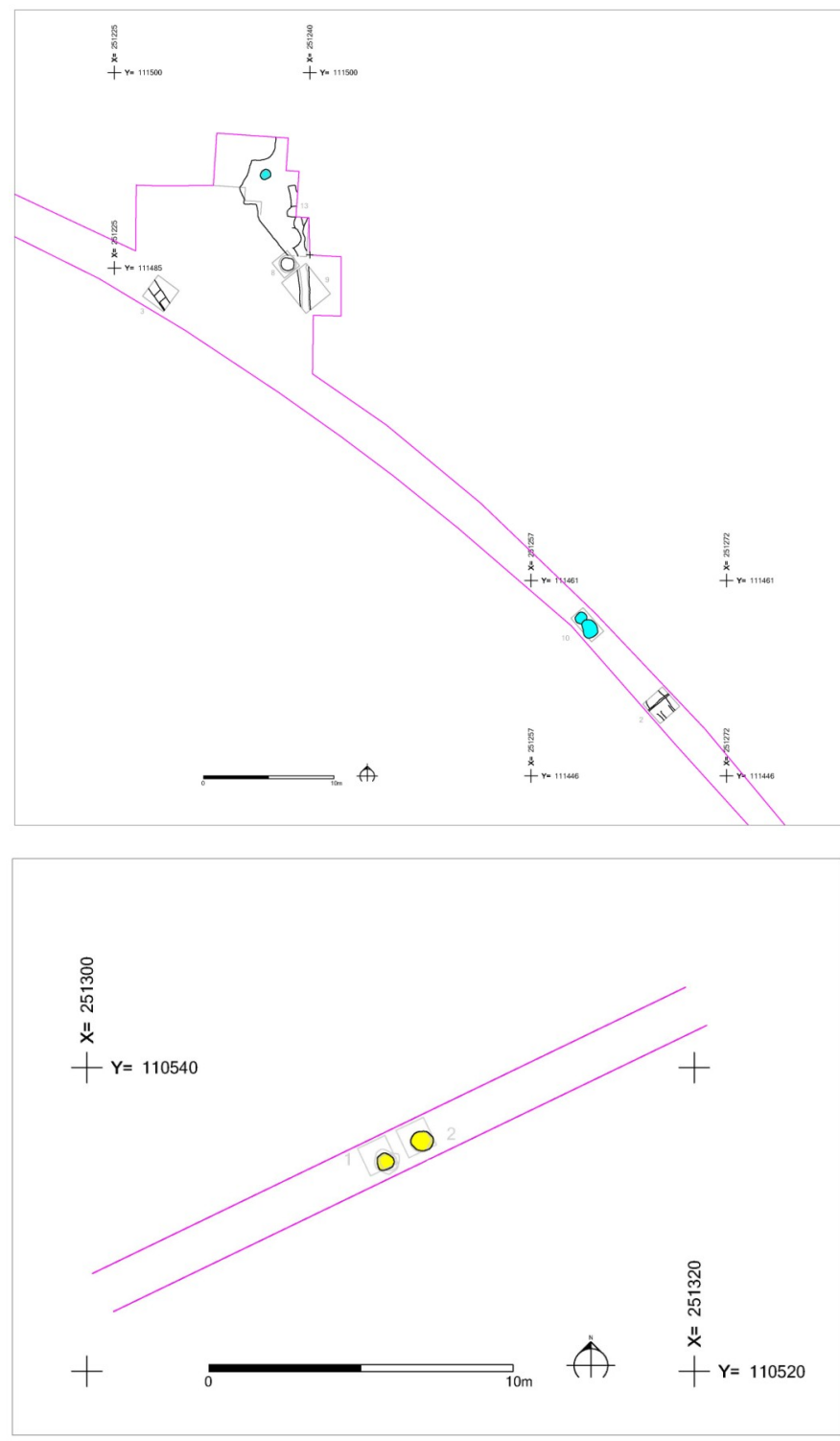

Fig. 28. Espicharrabo 4, planta geral da intervenção. Linha púrpura: limites de afetação do projeto; Azul claro: Pré-história Recente indeterminado; Sem preenchimento: outros contextos.

Fig. 28. Espicharrabo 4, general plan of the interventation. Purple line: pipeline's project limits; Light blue: Undetermined period of Late Prehistory; No color: other features.

Fig. 29. Alcaria 4 , planta geral da intervenção. Linha púrpura: limites de afetação do projeto; Amarelo: estrutura "vazia".

Fig. 29. Alcaria 4, general plan of the interventation Purple line: pipeline's project limits; Yellow: "empty" structure.

Fig. 30. Alcaria 5, planta geral da intervenção. Linha púrpura: limites de afetação do projeto; Amarelo: estrutura "vazia"; Azul claro: Préhistória Recente indeterminado.

Fig. 30. Alcaria 5, general plan of the interventation. Purple line: pipeline's project limits; Yellow: "empty" structure; Light blue: Undetermined period of Late Prehistory. 


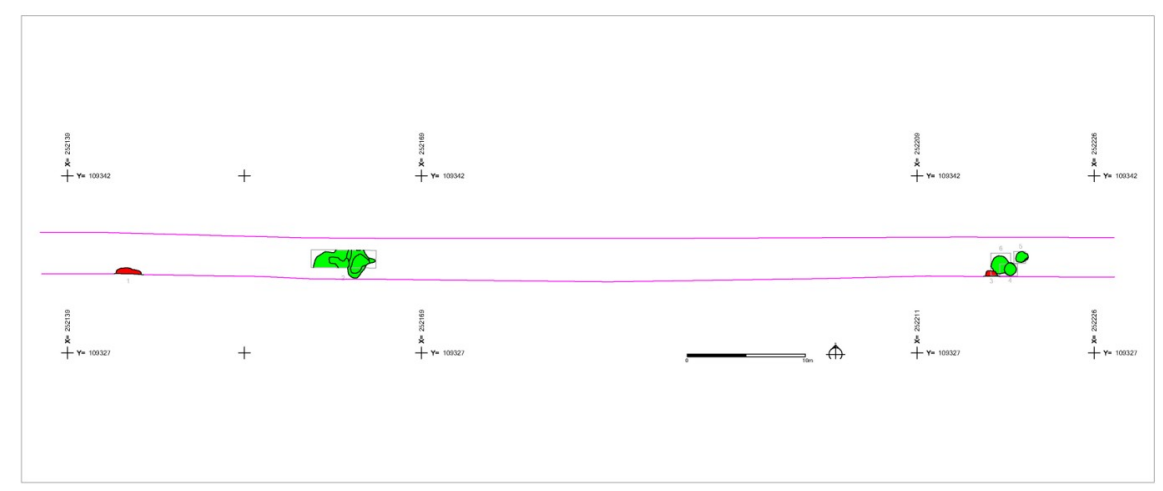

Fig. 31. Cidade das Rosas 4, planta geral da intervenção. Linha púrpura: limites de afetação do projeto; Verde: Idade do Bronze; Vermelho: contexto não escavado.

Fig. 31. Cidade das Rosas 4, general plan of the intervention. Purple line: pipeline's project limits; Green: Bronze Age; Red: non excavated feature.

associação à Idade do Bronze (ver BAPTISTA \& GOMES 2012c);

- Um conjunto de quatro estruturas em negativo de planta subcircular (Sondagens $3^{11}, 4,5$ e 6); as estruturas das sondagens 4, 5 e 6 apresentavam paredes tendencialmente retas e fundo plano, nos seus depósitos de enchimento foi exumado um conjunto cerâmico que remete também para Idade do Bronze (ibid.). É de salientar que, nesta concentração de estruturas, foi possível reconhecer uma sequência de construção, tendo-se registado uma posteridade estratigráfica da estrutura 4 relativamente à estrutura 6 , e da estrutura 6 relativamente à estrutura 3. Ou seja, trata-se de uma lógica de construção em que a adição de dispositivos arquitetónicos permite a sua sobreposição.

\subsection{Maria da Guarda 3}

Em Maria da Guarda 3 (BAPTISTA \& GOMES 2010c), foi identificado uma estrutura em negativo tipo hipogeu, articulável com a Idade do Bronze Regional (Fig. 32 e 33). Esta estrutura localiza-se no topo ondulado das elevações circundadas pelos Barrancos da Laje e da Morgadinha. O hipogeu é constituído por uma estrutura de acesso, que parece anterior à estrutura das inumações, uma zona de antecâmara e um nicho parietal, que se encontrava colmatado por uma estrutura pétrea. No interior do nicho, foram identificadas duas inumações: um indivíduo adulto de idade avançada do sexo feminino e um subadulto (de sexo indeterminado).

\subsection{Laje 2}

Em Laje 2 (BAPTISTA \& GOMES 2012b), os vestígios pré-históricos encontravam-se quase no topo da vertente virada ao Barranco da Laje. Foram realizadas duas sondagens: a Sondagem 1 permitiu diagnosticar uma descontinuidade no substrato, eventualmente associada a perturbações recentes decorrentes do plantio de árvores; a Sondagem 2 permitiu identificar uma estrutura em negativo de

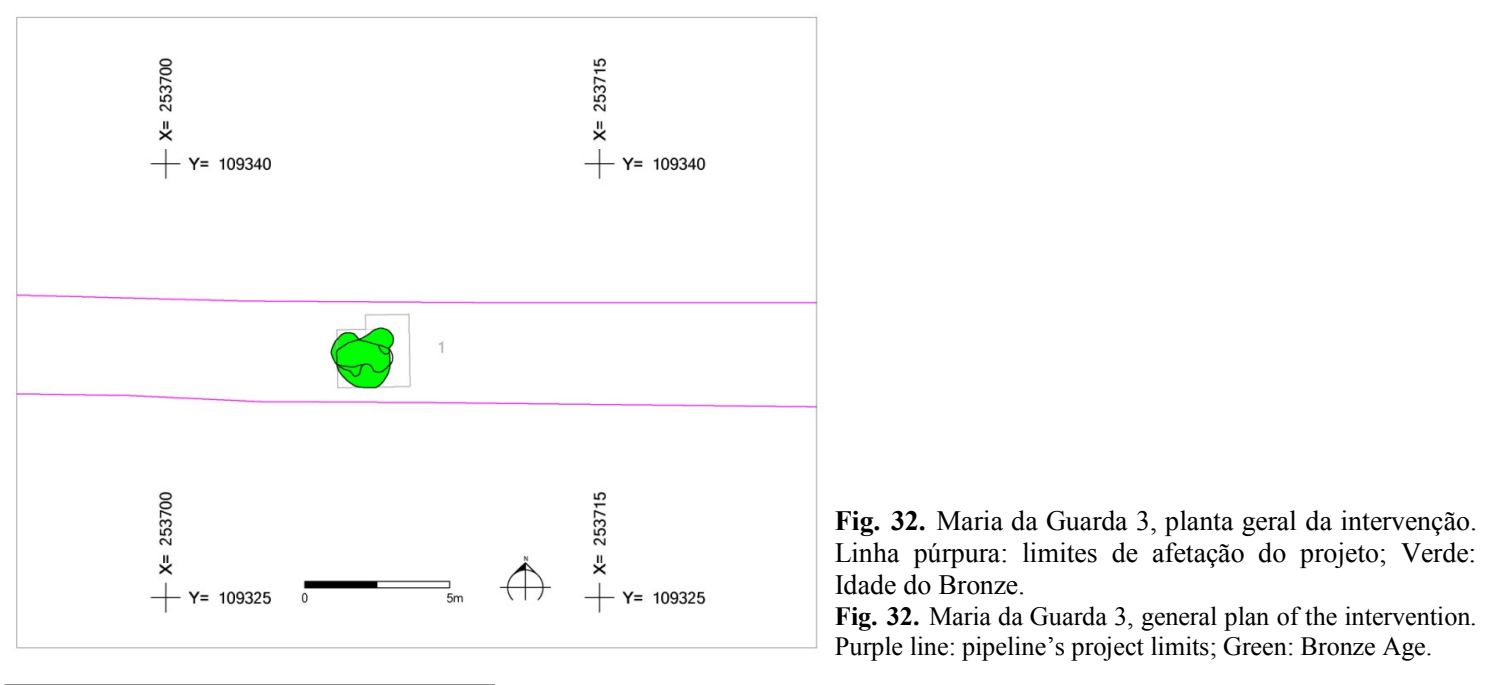

\footnotetext{
${ }^{11}$ Esta sondagem não foi realizada porque a implantação da conduta não implicava a sua afetação.
} 


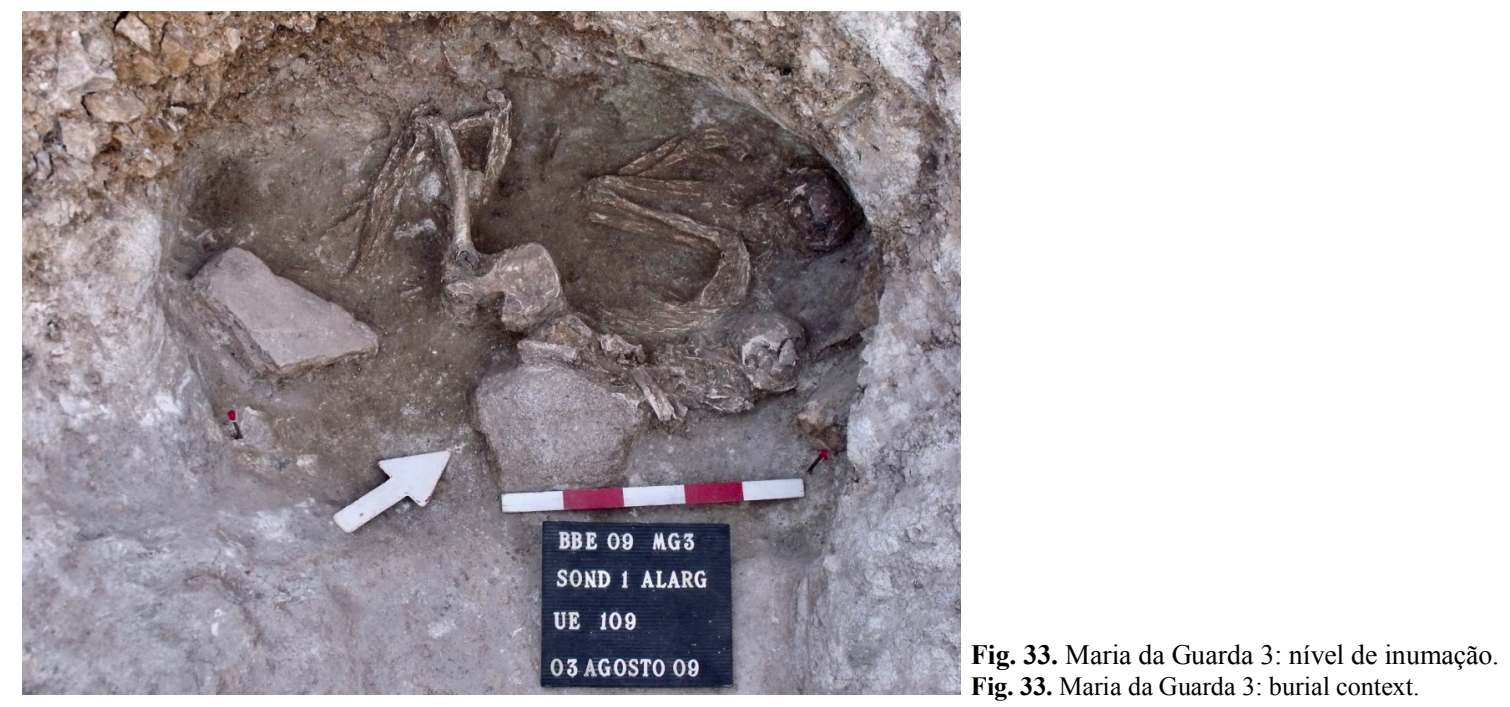

planta subcircular, paredes retas e fundo tendencialmente plano (Fig. 34), na base da qual se encontrava

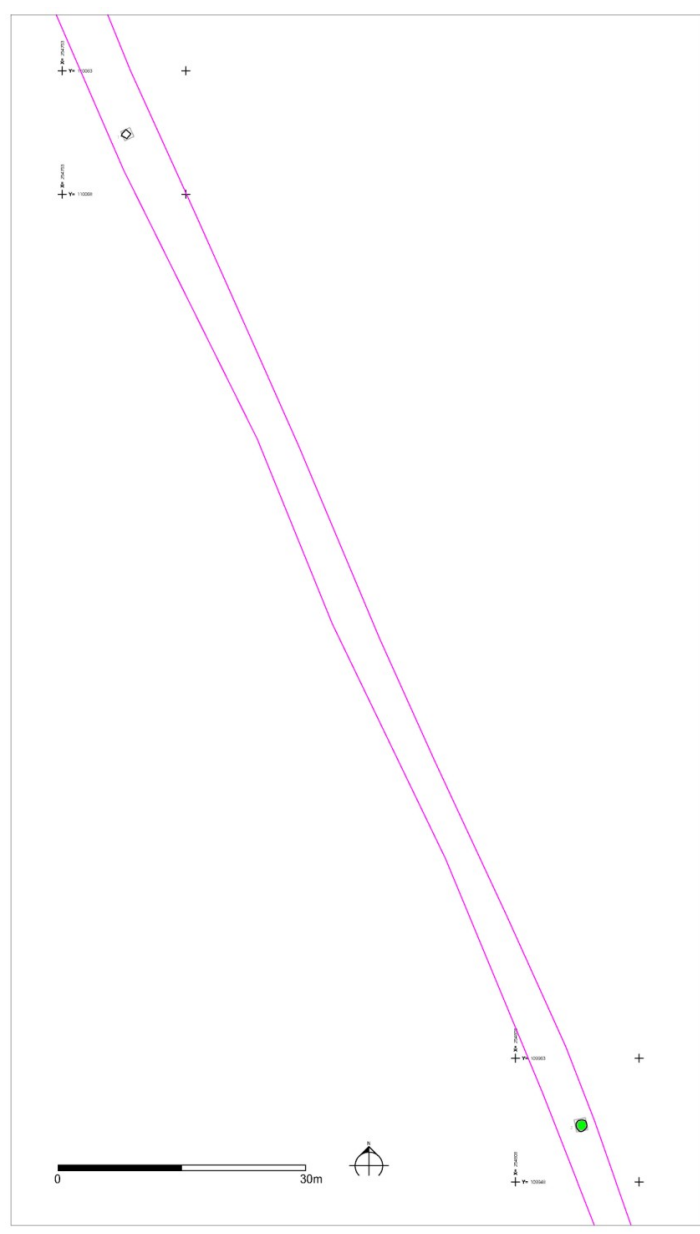

Fig. 34. Laje 2, planta geral da intervenção. Linha púrpura: limites de afetação do projeto; Verde: Idade do Bronze; Sem preenchimento: outros contextos.

Fig. 34. Laje 2, general plan of the interventation. Purple line: pipeline's project limits; Green: Bronze Age; No color: other features. um contexto de inumação enquadrável na Idade do Bronze regional. O enchimento da estrutura era praticamente constituído por um depósito de matriz argilosa, coloração castanha, compacto e heterogéneo, com inclusão de nódulos de caliço. Na base da estrutura, foram identificados dois indivíduos depositados sobre um depósito de fauna malacológica, aos quais se encontrava associada uma oferenda cárnica (Fig. 35). Os indivíduos (do sexo feminino, idade adulta) foram depositados em decúbito lateral e dispostos em "T", um com orientação E-W e o outro com orientação NS. O depósito de fauna malacológica é exclusivamente constituído por conchas (Unio sp). Entre os elementos malacológicos, registou-se a presença de fragmentos de recipientes cerâmicos e de elementos de tear.

\subsection{Monte da Laje}

Monte da Laje (BAPTISTA \& GOMES 2010d; MONTEIRO 2015) localiza-se a cerca de $1 \mathrm{~km}$ para SE de Laje 2, correspondendo a um conjunto de 19 estruturas (Fig. 37). Para além dos vestígios de cronologia pré-histórica, foi registado: uma estrutura com um nível de inumação, articulável com a Idade do Ferro (SOARES et al. 2016); e um conjunto de valados de cronologia indeterminada. No conjunto das estruturas de cronologia pré-histórica, é de salientar o seguinte:

- A ocorrência de uma componente cerâmica que permite a sua articulação com o Neolítico Final/ Calcolítico;

- A distribuição espacial das estruturas sugere o equacionamento de duas áreas (Fig. 37 e 38): a Área 1, onde se concentram 16 estruturas; e a Área 2 , na qual ocorrem, de modo aparentemente isolado, um conjunto de três estruturas;

- Em termos morfológicos, regista-se a presença preponderante de estruturas de formas semi- 

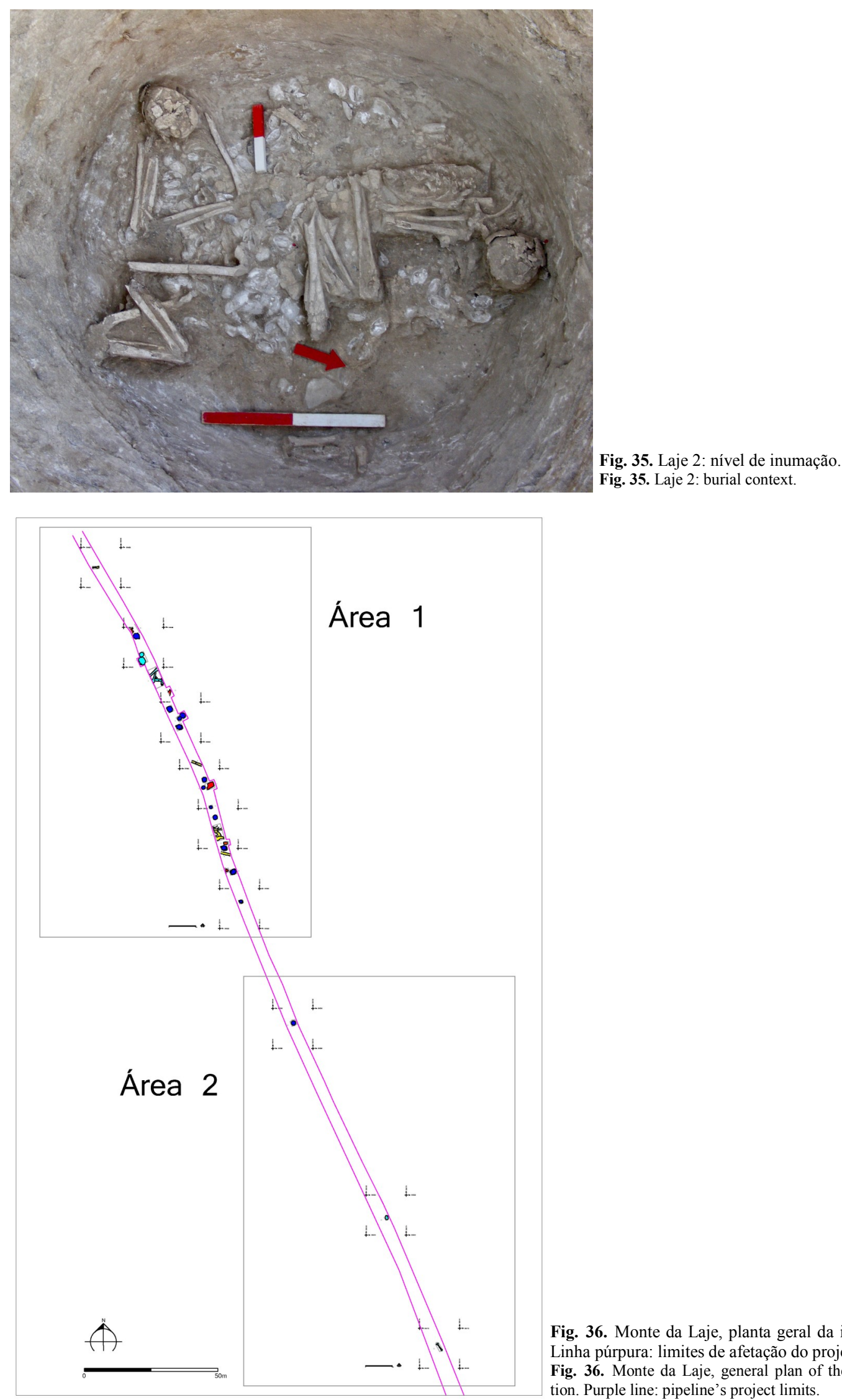

Fig. 36. Monte da Laje, planta geral da intervenção. Linha púrpura: limites de afetação do projeto.

Fig. 36. Monte da Laje, general plan of the interventation. Purple line: pipeline's project limits. 


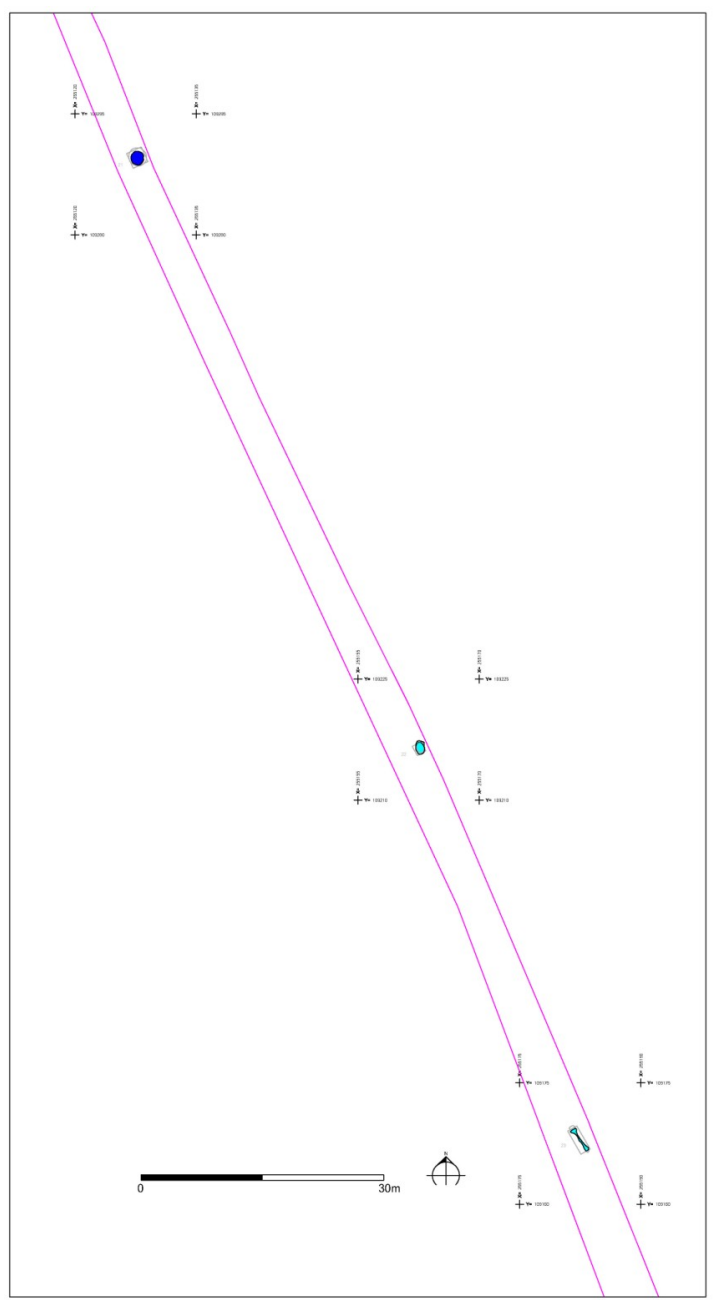

Fig. 37. Monte da Laje, Área 1. Linha púrpura: limites de afetação do projeto; Amarelo: estrutura "vazia"; Azul claro: Pré-história Recente indeterminado; Azul escuro: Neolítico Final/Calcolítico; Vermelho: contexto não escavado.

Fig. 37. Monte da Laje, Area 1. Purple line: pipeline's project limits; Yellow: "empty" structure; Light blue: Undetermined period of Late Prehistory; Dark blue: Late Neolithic/Calcolithic; Red: non excavated feature.

globular, duas estruturas de planta em forma de 8 , uma estrutura de planta em forma de osso e uma estrutura de planta subretangular alongada;

- Quando considerada a distribuição espacial do tipo de estruturas, note-se que a planta em forma de osso e a estrutura de planta subretangular alongada estão localizadas nos limites da área onde ocorrem as estruturas;

- Os enchimentos das estruturas apresentam depósitos argilosos, nos quais ocorrem blocos pétreos (concentrados ou isolados), fragmentos de recipientes cerâmicos, elementos de tear (fragmentos ou inteiros), indústria lítica (nomeadamente material polido) e vestígios de fauna mamalógica. De um modo geral, a componente

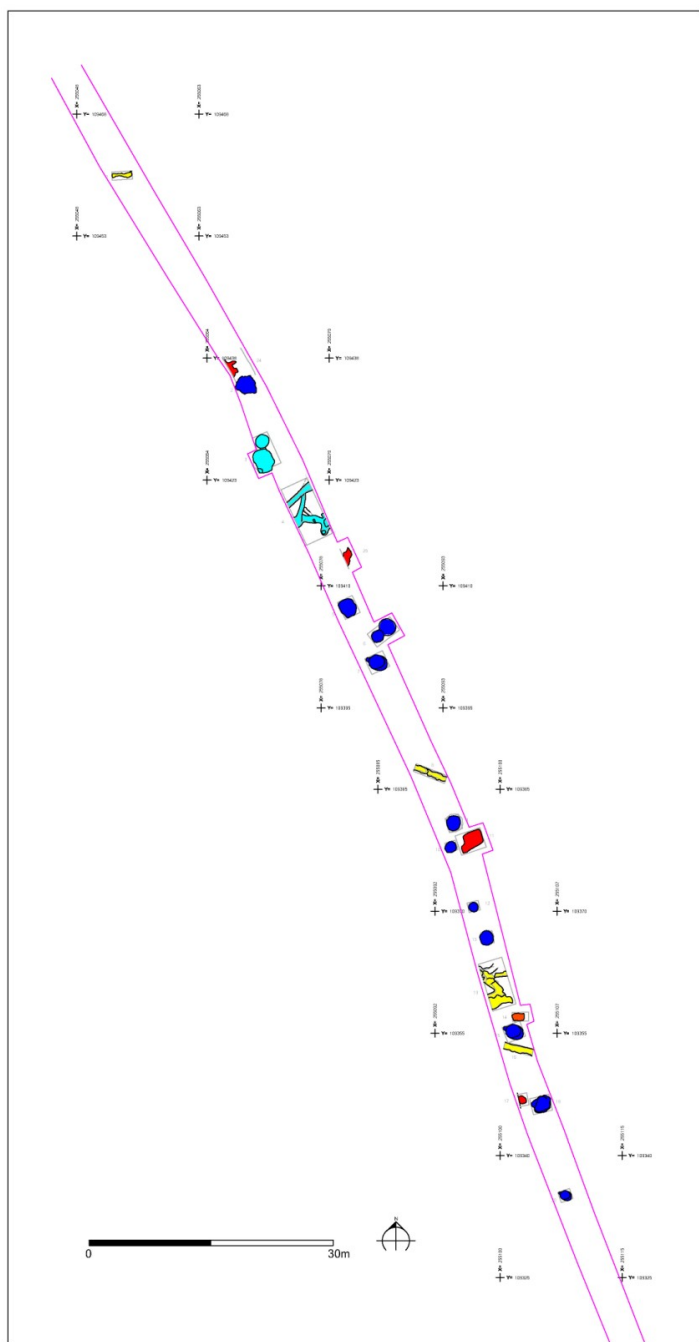

Fig. 38. Monte da Laje, Área 2. Linha púrpura: limites de afetação do projeto; Azul claro: Pré-história Recente indeterminado; Azul escuro: Transição Neolítico Final/Calcolítico.

Fig. 38. Monte da Laje, Area 2. Purple line: pipeline's project limits; Light blue: Undetermined period of Late Prehistory; Dark blue: Late Neolithic/Calcolithic transition.

artefactual e a fauna ocorre de modo pouco formalizado, porém, na estrutura da Sondagem 2, o topo do enchimento apresentava um nível onde se registava a presença de um depósito arqueofaunístico (bovídeo), uma concentração de blocos de gabro e fragmentos de recipientes cerâmicos ${ }^{12}$ (Fig. 39).

\subsection{Vale de Éguas 3}

Vale de Éguas 3 (CuNHA et al. 2010d) localiza-se numa zona elevada, com uma ondulação muito suave, na área onde se começa a formar o Barranco da Morgadinha. Os trabalhos de decapagem mecânica permitiram a identificação de uma concentração de seis estruturas de planta de subcircular (Fig. 40). A componente cerâmica exumada no interior das estruturas permite a sua associação

\footnotetext{
${ }^{12}$ Para mais informação sobre a componente artefactual e faunística das estruturas, consultar o trabalho de N. Monteiro (2015).
} 


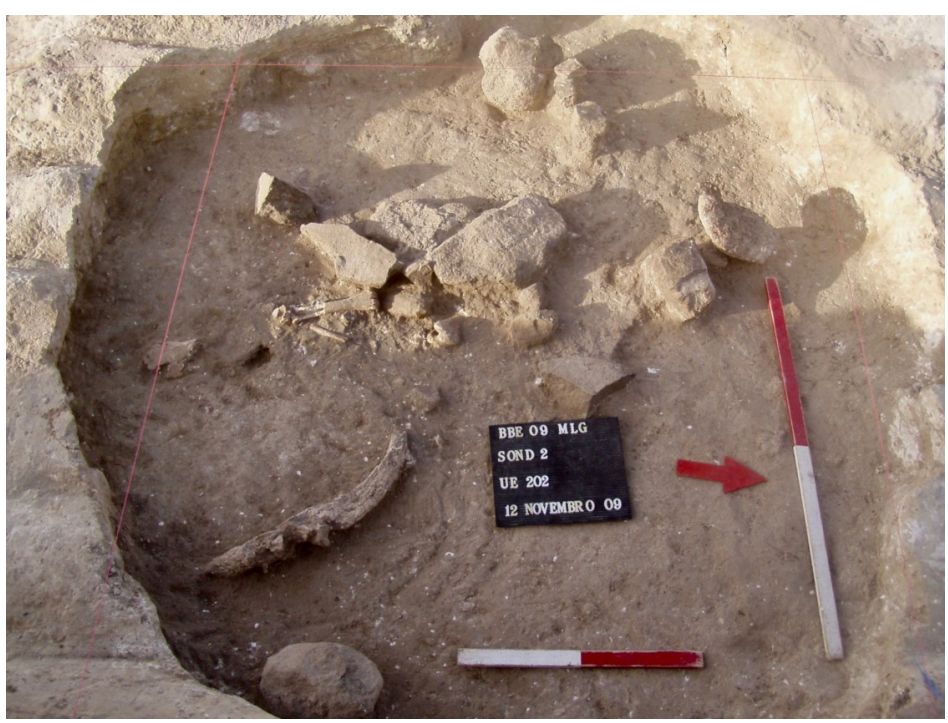

Fig. 39. Monte da Laje, nível de deposição. Fig. 39. Monte da Laje, deposition context.

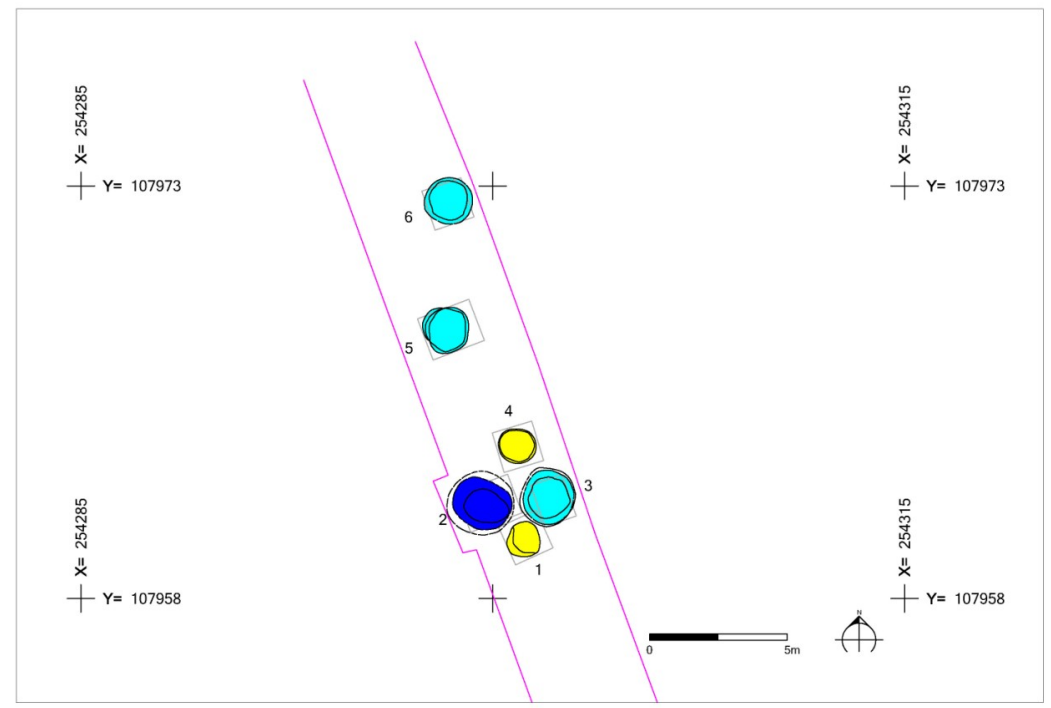

Fig. 40. Vale de Éguas 3, planta geral da intervenção. Linha púrpura: limites de afetação do projeto; Amarelo: estrutura "vazia"; Azul claro: Pré-história Recente indeterminado; Azul escuro: Calcolítico.

Fig. 40. Vale de Éguas 3, general plan of the interventation. Purple line: pipeline's project limits; Yellow: "empty" structure; Light blue: Undetermined period of Late Prehistory; Dark blue: Calcolithic.

ao Calcolítico regional. A uma distância de cerca de $100 \mathrm{~m}$ deste conjunto de estruturas, foi identificado um depósito que parecia corresponder ao enchimento de uma estrutura de planta subretangular, que se desenvolvia para lá dos limites da área decapada. Uma vez que tal contexto não viria a ser afetado pelos trabalhos de implantação da conduta, não se procedeu à sua escavação.

A distribuição espacial das estruturas da concentração permite equacionar dois grupos. O Grupo 1, ao qual pertencem estruturas das Sondagens $1,2,3$ e 4 , define-se pela proximidade espacial entre estas estruturas, sugerindo estar distribuídas em função de um ponto central. Em termos morfo- lógicos, é de salientar o seguinte: as estruturas 2 e 3 apresentam formas fechadas e uma profundidade $1,2 \mathrm{~m}$ e 1,4 $\mathrm{m}$, respetivamente; as estruturas 1 e 4 apresentam formas abertas e uma profundidade 0,4 $\mathrm{m}$. No enchimento das estruturas, regista-se que: as estruturas 1 e 4 apresentam um único depósito, sem qualquer elemento artefactual; as estruturas 2 e 3 apresentam uma sequência complexa, constituída por vários depósitos de enchimento, na qual ocorrem fragmentos cerâmicos e, na estrutura 3 , um fragmento de um dormente. A análise da componente cerâmica da estrutura 2 remete para distintas dinâmicas de fragmentação e deposição. O Grupo 2 é constituído pelas estruturas das Sondagens 5 e 
6. A estrutura 5 encontra-se a cerca de $2 \mathrm{~m}$ do Grupo 1 e a estrutura 6 a cerca de 4 m. Refira-se que esta distribuição contrasta com a proximidade das estruturas do Grupo 1. Em termos morfológicos, apresentam formas tendencialmente fechadas, com profundidade de $1 \mathrm{~m}$ (estrutura 5) e $0,7 \mathrm{~m}$ (estrutura 6). Os enchimentos destas estruturas eram constituídos por um único depósito, no qual se encontravam fragmentos cerâmicos.

Como referimos, o enchimento da estrutura 2 apresenta uma componente cerâmica, cuja análise remete para distintas práticas de fragmentação e deposição (Figuras 41 e 42). Com efeito, no topo do segundo depósito de enchimento, foi identificada uma parte de um prato de bordo espessado. Abaixo deste nível de deposição, os depósitos embalavam fragmentos de um recipiente esférico fechado, tendo-se registado que, tendencialmente, os fragmentos da base do recipiente se encontravam nos depósitos superiores e os fragmentos do bordo nos depósitos inferiores (ver BAPTISTA \& GOMES 2012d).

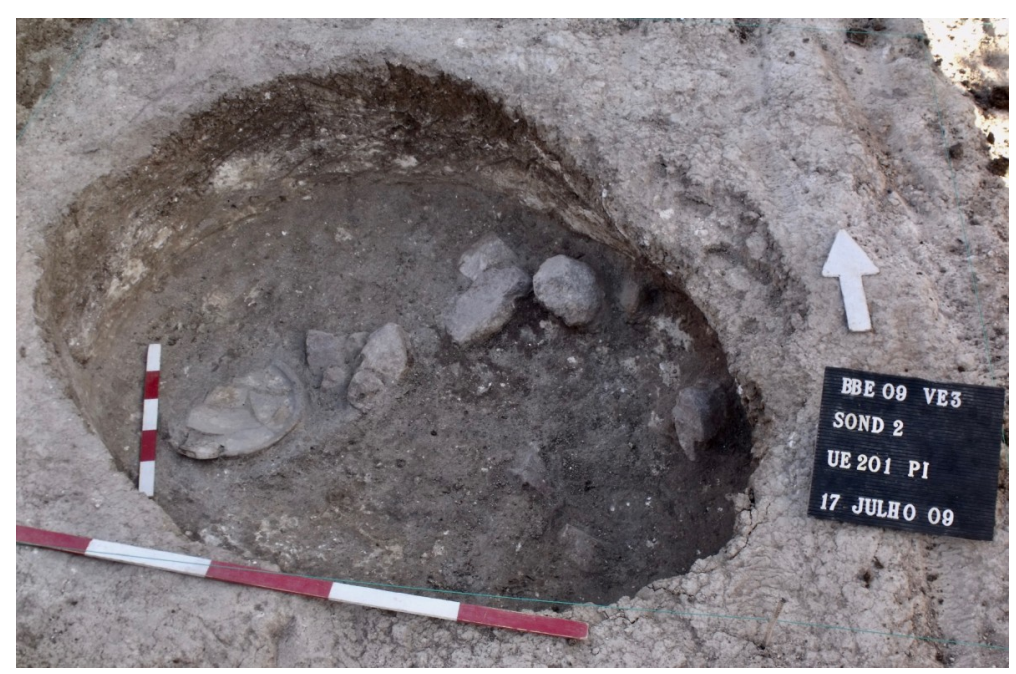

Fig. 41. Vale de Éguas 3: nível de deposição de parte de um prato de bordo espessado. Fig. 41. Vale de Éguas 3: deposition context of a part of a reinforced-rimmed plate.

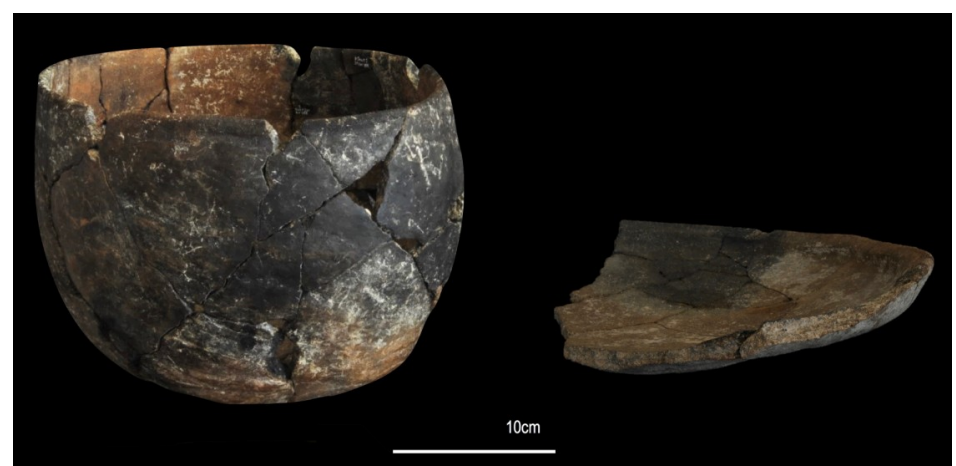

Fig. 42. Vale de Éguas 3: recipientes cerâmicos do enchimento da estrutura apresentada na figura anterior.

Fig. 42. Vale de Éguas 3: ceramic elements from the fills of the structure presented in the previous figure.

\subsection{Síntese}

A descrição que acabamos de apresentar acerca dos resultados obtidos nas diferentes intervenções é muito sumária. Com efeito, para dar conta da complexidade dos contextos de Horta da Morgadinha e Horta da Morgadinha 2, por exemplo, seria necessária uma apresentação mais pormenorizada que excede os objetivos deste texto. Não obstante estes limites, parece-nos que a apresentação nos permite elencar um conjunto de aspe- tos que caracterizam, em linhas gerais, a base empírica em estudo:

- As estruturas ocorrem, de modo mais concentrado ou disperso, em diferentes pontos das colinas, não se tendo verificado um dispositivo que demarque, de modo inequívoco, tal distribuição;

- Em termos cronológicos, ocorrem conjuntos artefactuais que remetem para uma ocupação entre o Neolítico Final e a Idade do Bronze, sendo 
comum a ocorrência de contextos de cronologia distinta em espaços contíguos;

- As estruturas apresentam morfologias distintas, que podem ser agrupadas do seguinte modo: fossas, estruturas de planta subretangular, uma estrutura de planta em forma de osso, dois hipogeus e um fosso;

- Quando consideramos a distribuição espacial das diferentes morfologias de estruturas é de salientar que:

- no caso das fossas, é possível reconhecer a existência de áreas de grande concentração de estruturas e áreas onde ocorrem de modo disperso;

- as estruturas de planta subretangular, de Horta da Morgadinha, organizam-se em linhas paralelas, sugerindo a configuração de corredores;

- a estrutura de planta em forma de osso, em Monte da Laje, encontra-se num dos extremos da área onde ocorrem as restantes estruturas, opondo-se a uma estrutura de planta subretangular alongada localizada no outro extremo;

- o hipogeu de Maria da Guarda ocorre de modo isolado; o de Horta da Morgadinha é posterior às estruturas de planta subretangular, sugerindo também ocorrer de modo isolado;

- No que diz respeito ao enchimento, registase um elevado número de estruturas que apresentavam sequências compostas por um ou dois depósitos de matriz argilosa, que embalavam fragmentos de recipientes cerâmicos, indústria lítica, elementos metálicos e vestígios faunísticos; a par destas sequências, regista-se também enchimentos que articulam depósitos argilosos com níveis pétreos; e, por último, estruturas que apresentam níveis de deposição de diferentes categorias de materiais (designadamente cerâmicos e líticos, com diferentes graus de integridade física), de cadáveres de animais ou outros depósitos arqueofaunísticos e de inumações humanas. As estruturas com as sequências de enchimento complexas estão mais presentes em Horta da Morgadinha e Horta da Morgadinha 2.
Estas características gerais permitem compreender o modo como a unidade de estudo se encaixa sem grandes desvios nas dinâmicas de ocupação conhecidas para a Pré-história Recente deste troço da margem esquerda do Guadiana (e.g., AlVES et al. 2014; BAPTISTA \& GOMES 2013a; VALERA et al. 2014). Com efeito, apesar das diferenças ${ }^{13}$, é de salientar as inúmeras semelhanças que permitem o equacionamento de um "mundo em negativo" (VALERA et al. ibid.) que concorre na edificação das condições de vida das comunidades pré-históricas, contrastando com outros modos de construção, como o megalitismo ou os recintos murados, que se desenvolvem em regiões contíguas (DINIZ 1999; PARREIRA 1983; RODRIGUES \& MARTINS 2005; SOARES 1992, 1994, 2005, 2008; SOARES \& ARNAUD 1984). Nas inúmeras semelhanças que forjam a unidade do "mundo em negativo" da Pré-história Recente, é de destacar que algumas das estruturas apresentam um enchimento que parece albergar uma associação intencional entre diferentes participantes desse mundo. Os níveis de deposição de materiais e de inumação expressam uma prática de congregação de diferentes elementos que, uma vez depositados no interior das estruturas, participam na consignação de ordens (i) materiais que possam ter condicionado os limites e as possibilidades de ação das comunidades construtoras destas estruturas ${ }^{14}$. Neste sentido, na compreensão deste "mundo em negativo" é necessário dar ênfase ao entrelaçamento de:

- uma prática de construção em negativo, na qual as estruturas são dispositivos que acionam relações entre pré-existências e projetos de transformação do espaço, (re)negociando as condições do papel que desempenham nesta dinâmica;

- e de práticas de deposição, na qual o interior da estrutura é o espaço de acolhimento à expressividade (i)material de uma erótica na qual se transforma o leque de ligações entre os diferentes participantes que constituem e refazem a comunidade.

Dando ênfase a esta relação entre a construção (como modo de moldar e refazer unidades espaciais e temporais) e a deposição (como modo de atualização de ligações entre as entidades que constituem e atualizam essas unidades), estamos a trazer ao de cima uma relação entre arquitetura e arquivo que será desenvolvida no próximo ponto.

\footnotetext{
${ }^{13}$ A título de exemplo, podemos salientar alguns aspetos relacionados com o tipo de estruturas e as relações espaciais que estabelecem entre si: a exclusiva ocorrência de hipogeus isolados, que contrasta com os núcleos de Montinhos 6 (Baptista 2013) e Torre Velha 3 (Alves et al. 2014); o modo como se distribuem as estruturas em forma de osso em Monte da Lage e as configurações que apresentam em Santo Estêvão e Montinhos 6 (Baptista \& Gomes $2013 b$ ); a aparente exclusividade do conjunto de estruturas de planta subretangular de Horta da Morgadinha; ou a maior ocorrência de recintos de fossos na margem direita da Ribeira do Enxoé (Valera et al. 2014). Relativamente aos fossos, é também de referir a cronologia tardia do fosso de Horta da Morgadinha 2 quando comparada com os recintos de Cortes 1 e Outeiro Alto 2 (ibid.), sendo de destacar que não é caso único como indica a componente cerâmica do enchimento do fosso de um recinto recentemente descoberto no sítio Monte Branco 5, em Pias, (Baptista \& Vale 2017). Note-se que estas diferenças devem ser consideradas com cautel dado que o programa de intervenções efetuado não corresponde, como já referimos, ao desenvolvimento de um inquérito que nos viabilize um exercício de comparação metodologicamente sustentado.

${ }^{14}$ Esta tradição arquitetónica e estas práticas de deposição estão a ser discutidas num intervalo de tempo muito amplo, carecendo de uma perspetiva diacrónica que permite qualificar e compreender as suas especificidades ao longo do tempo. É nosso propósito proceder a esta discussão trabalhos futuros.
} 


\section{ARQUITETURA E ARQUIVO}

A unidade de estudo convoca uma relação entre arquitetura e arquivo. Esta relação, longe de constituir uma especifícidade da tradição arquitetónica em análise, pode ser pensada a partir de qualquer dispositivo arquitetónico ou arquivístico. Com efeito, tanto arquitetura como arquivo são formas de criação e transformação do espaço e do tempo, na medida em que estabelecem ordens e limites que orientam a sua experimentação. Em arqueologia préhistórica, a arquitetura é um tópico discutido por vários autores, nomeadamente como estratégia para problematizar as modalidades de experienciar o espaço e de agilizar a pesquisa das relações entre determinados dispositivos arquitetónicos e a sua envolvente ${ }^{15}$. O arquivo, por sua vez, não se formalizou enquanto campo ou problemática de análise vigente. Todavia, se considerarmos as inúmeras questões que emergem na discussão de tópicos como a deposição (e.g., THOMAS 1999; GARROW 2012), a biografia de materiais (e.g., GOSDEN \& MARSHAL 1999; INGOLD 2002; JONES et al. 2016), a dimensão social da fragmentação de objetos (e.g., CHAPMAN 2000; CHAPMAN \& GAYDARSKA 2007), arqueologia e memória (e.g., Jones 2007), a vida social dos objetos (e.g., RENFREW 1998), a arqueologia das coisas (e.g., OLSEN et al. 2007; OLSEN 2010), a arqueologia das ligações (e.g., HODDER 2012), a assemblage theory (e.g. HAMILAKIS 2017; HAMILAKIS \& JONES 2016) ou a fluidez e permeabilidade das categorias ontológicas (e.g. FOWler 2004; HALlOWEll 1960; HeNARE et al. 2007; VALERA 2016), podemos ver que muitas delas estão, implicitamente, relacionadas com as práticas de congregação e consignação que são inerentes à constituição dos arquivos, enquanto espaços de saber e de poder, e ao seu papel na inauguração, manutenção e abandono de laços comunitários e de sentido(s) para o devir do mundo.

A ideia de arquivo que começamos a delinear no parágrafo anterior é apresentada por J. DERRIDA (2001), no seu ensaio Mal de Arquivo. O autor afasta-nos da ideia burocrática e administrativa que podemos ter do arquivo para, em relação com essa ideia, esboçar uma noção onde o arquivo é um espaço técnico, político, jurídico e ético, no qual o porvir da verdade e o porvir da memória são negociados. $\mathrm{O}$ ensaio de DERRIDA (ibid.) começa com a palavra arquivo. Começa com o modo como tal palavra acolhe em si a palavra grega arkhê. Na dinâmica da palavra, são salientados os seguintes pontos:

- Na relação com a arkhê, o arquivo funda-se na congregação de dois princípios que trespassam a arkhê: o princípio de começo e o princípio de comando, constituindo-se enquanto um ali onde do começo das coisas (origem física, histórica e ontológica) e um ali onde do comando e da lei (origem nomológica). $\mathrm{O}$ arquivo é, então, um ali onde se congregam e consignam as coisas, estabelecendo-se a domiciliação de uma ordem física, histórica, ontológica e nomológica para a comunidade, ou a ecologia, desse arquivo. A congregação dos princípios de começo e comando implica, porém, a constituição de uma arena para a conjugação das forças, por vezes dissonantes, provenientes da origem física, histórica, ontológica e nomológica dos participantes no arquivo. Nesta conjugação das forças, há um trabalho de configuração a fazer; um trabalho de configuração no qual a comunidade se (re)faz entre o porvir das suas condições de existência.

- O segundo ponto salientado por DERRIDA prende-se à maneira pela qual $\mathrm{o}$ arquivo acolhe a palavra arkhê, escrevendo que: "É bem verdade que o conceito de arquivo abriga em si mesmo esta memória do nome arkhê. Mas também se conserva ao abrigo desta memória que ele abriga: é o mesmo que dizer que a esquece" (ibid.: 12). Neste esquecimento da arkhê, ou no esquecimento de que o arquivo é um trabalho com o (des)alinhamento de forças físicas, históricas, ontológicas e nomológicas, o arquivo tenta esquivar-se à contingência em que se faz esse trabalho para reforçar a sua autoridade enquanto repositório estável. O arquivo é um trabalho de criação e destruição das possibilidades e dos limites do porvir potenciado na congregação dos princípios de começo e comando. Neste contexto, criação e destruição são modos imbricados de transformação do mundo, na medida em que a criação ou a estabilização de determinadas condições de mudança implica a transformação ou a destruição de condições que poderiam colocar em causa uma determinada orientação da transformação.

Neste trabalho, o ali onde do arquivo é um espaço para se ter em conta aquilo que, pela edificação, a prática de arquivo tornou pensável e conhecível e, pela destruição, converteu em impensável, lançando-o para uma zona de desconhecimento. $\mathrm{O}$ arquivo é, então, um espaço de (des)cristalização de um pensamento ético e de (des)autorização de práticas técnicas, políticas e jurídicas.

$\mathrm{O}$ arquivo que DERRIDA (ibid.) nos dá a conceber é um ali onde do (im)pensável e do (des) conhecimento, onde se cruza a temporalidade factual (projetado pelo pensamento e pelo conhecimento) e a temporalidade messiânica (invocado face ao impensável e ao desconhecimento). O que de impensado ou desconhecido se produz no arquivo não tem uma carga meramente negativa; não é apenas um limite. A ser uma zona limite, é o espaço que

${ }^{15}$ Para o espaço peninsular ver, por exemplo, os trabalhos de F. Criado-Boado (e.g., 1993), L. Evangelista (2003), S. Jorge (e.g., 1998, 2004, 2007); V. Jorge (et al. 2006b), M. Lago (et al. 1998), J. Márquez Romero e V. Jiménez-Jaiméz (2010), J. Muralha (2010), A. Santos (2008), J. Soares (2014), A. Sousa (2010), A. Valera (e.g., 2007, 2012, 2016), A. Vale (2011) e G. Velho (2009). 
“envolve a história do conceito, articula o desejo ou o mal de arquivo, a sua abertura para o futuro, a sua dependência em relação ao que está por vir, em suma, tudo o que liga o saber e a memória à promessa" (ibid.: 45). O arquivo não se constitui apenas como lugar de controle das derivações dos factos, mas enquanto lugar de transformação das condições desses factos. É um lugar de experiência sob o signo da promessa; é um lugar onde a experiência se faz para exceder a facticidade.

Esta noção de arquivo, elaborada a partir da palavra arquivo, abre-nos a possibilidade para pensarmos a palavra arquitetura (arkhê + tekhnê). A arquitetura, acolhendo em si uma relação com a arkhê semelhante à do arquivo (ou seja, abrigando e abrigando-se da arkhê), faz-nos pensar a arquitetura como uma técnica (tekhnê) de mediação da congregação dos princípios de começo e comando, uma prática de edificação e destruição com a qual se orientam os saberes e os poderes emergentes na experiência do espaço, e uma prática onde se afere o peso da sua facticidade e a força da sua promessa na negociação do(s) sentido(s). Tal noção de arquivo alerta-nos também para a intimidade existente entre arquivo e arquitetura enquanto modos de intervenção no devir. Um dispositivo arquitetónico é, simultaneamente, um dispositivo arquivístico: é a configuração de um conjunto de relações que condiciona a modelação do espaço; é um dispositivo que ativa uma dinâmica de inclusão/exclusão, ordenando as zonas do (in)pensável e do (des)conhecimento; é uma congregação e consignação de materiais, formas e movimentos, nas quais se estabelecem as condições para experienciar os factos e as promessas. Um dispositivo arquitetónico, uma estrutura em negativo, por exemplo, é um entrelaçamento de arquitetura e arquivo que, nesse entrelaçamento, faz da sua construção uma manifestação material das práticas de cuidado que visam a transformação das possibilidades e limites das condições de ação.

Arquitetura e arquivo propõem uma relação articulada e orientada de criação e destruição, que é necessário ter em conta quando estudamos as estruturas em negativo que apresentamos no ponto anterior. Uma das grandes dificuldades no estudo destas estruturas é de conhecer as suas biografias, isto é, de as pensar em função dos múltiplos cenários em que podem ter participado: cenários nos quais a sua configuração pode ter sido alterada, quer pelo acrescento de módulos ou por uma compartimentação do seu interior; cenários nos quais se pode ter mudado a natureza dos elementos que são depositados no seu anterior ou os processos/práticas do seu enchimento; e cenários que, colocando em diálogo diferentes elementos, refazem as delimitações espaciais e temporais das estruturas, colocando-as enquanto dispositivos ativos ou dispositivos à margem de uma determinada dinâmica. É neste sentido que deve ser entendido o binómio criação/destruição acima referido, ou seja, enquanto estratégia para operacionalizar um ponto de vista que posiciona as estruturas enquanto um dispositivo que refaz condições prévias e cria novas condições de ação e que, entre estas condições, tanto pode emergir, como pode ser transformada ou desaparecer do contexto histórico.

O binómio criação/destruição permite, então, considerar que estas estruturas se inserem em diferentes dinâmicas que condicionam a sua incorporação, transformação e rejeição. Neste sentido, é de salientar que, por um lado, há estruturas cujo enchimento parece comportar uma acumulação de ações de associação entre diferentes elementos que, neste processo, é preservada ${ }^{16}$. Por outro lado, e em contraste com este arquivamento edificante, há estruturas que parecem estar vazias, como que albergando os resíduos de uma prática de destruição ou apagamento de eventuais enchimentos anteriores ${ }^{17}$. Entre estes dois cenários, há estruturas que albergam elementos que ocorrem de modo, aparentemente, aleatório e com uma expressão residual que, nesta ambiguidade, nos fazem questionar o tipo de práticas/processos (de criação/destruição) que podem explicar a sua ocorrência ${ }^{18}$. Para além destas questões, centradas no enchimento das estruturas, há relações de criação/destruição que podem ser colocadas a estruturas que, separadas no tempo, se acumulam no mesmo espaço, destruindo uma lógica de distribuição espacial prévia e inaugurando outro movimento no processo de monumentalização da paisagem. Acresce referir que nestas questões, que se constituem na análise da facticidade da base empírica entretanto produzida, a arquitetura e o arquivo, enquanto práticas de criação/destruição, alertam para aquilo que está em falta; aquilo que as práticas de arquitetura e arquivo desenvolvidas pelas comunidades pré-históricas fizeram desaparecer na constituição das suas ordens; ou lançaram para a zona do impensável e do desconhecimento para viabilizar a singularidade do cuidado para com o seu mundo. Ou seja, arquitetura e arquivo entrelaçados

\footnotetext{
${ }^{16}$ A propósito de estruturas com sequências de enchimento complexas sugere-se a consulta da análise que apresentamos acerca de alguns dos contextos referidos anteriormente (Baptista \& Gomes 2012d; Baptista 2013; Baptista \& Gomes 2013a; Gomes et al. 2013a; Gomes et al 2013b). Nestas estruturas, a associação entre elementos sugere-nos relações entre diferentes elementos, cuja razão para ter sido preservada nos escapa. Porém, deve também colocar-se a hipótese de tais associações serem apenas um momento de uma biografia do relacionamento entre tais elementos, na qual se apaga (destrói) uma ligação para se dar lugar (criar) uma outra rede.

${ }^{17}$ A este propósito refira-se a análise que A. Valera e V. Filipe (2012) desenvolvem a propósito de um conjunto de estruturas vazias, em articulação espacial com estruturas de enterramento, de Outeiro Alto 2. A análise morfológica e a distribuição espacial permitiram-lhes a associação de tal conjunto de estruturas a um recinto de postes (de madeira e/ou pedra) que, não teria deixado vestígios, para além dos negativos. Face a esta inexistência de vestígios, pode colocar-se a hipótese de tal construção ter sido desmantelada, levando a que tal cenário deixe de ser visível ou tenha sido apagado (destruído ou rejeitado) enquanto dispositivo material, ficando à margem das condições materiais de outros cenários que tal desmantelamento possa ter proporcionado.

${ }^{18}$ Acrescente-se que todo este processo de compreensão dos enchimentos e das relações entre estruturas tem necessariamente de considerar os processos de formação do registo arqueológico (e.g. Schiffer 1987). O conhecimento de tais processos de formação permite, por um lado, aferir a natureza das relações entre os diferentes elementos compõem o registo e, por outro lado, explorar as possibilidades de exceder a sua natureza de resíduo (Lucas 2012: 210-214).
} 
fazem-nos pensar naquilo que a facticidade das bases empíricas apagou, obrigando-nos a reconduzir a sua experiência à procura das (im)pensáveis questões e do (des)conhecimento das razões que seguram os factos.

Nesta relação entre arquitetura e arquivo encontramos um modo possível de operacionalizar e gerir a pesquisa da unidade de estudo. Uma operacionalização da pesquisa que passa por uma (des) articulação de inquéritos, por um jogo de cruzamento de escalas de análise e de comparação e, por conseguinte, por uma interseção de procedimentos analíticos no sentido de multiplicar pontos de vista e possibilidades de conhecer estes vestígios arqueológicos. Uma gestão da pesquisa que é ciente dos limites e possibilidades da base empírica que se encontra a estudar, bem como dos recursos de que dispomos para ultrapassar tais condicionalismos. A redação deste texto corresponde a uma gestão desses condicionalismos e recursos. É um texto que se apoia na apresentação de dados e na descrição de uma orientação teórico-metodológica para a sua análise; é um texto no qual falta uma escala intermédia de discussão que demonstre algumas das ideias apresentadas. No entanto, decidiu-se a sua publicação enquanto ponto de referência para gerir a produção de outros estudos que terão o propósito de incidir a tal escala. Por último, devemos acrescentar que, para além desta operacionalização e gestão, a relação entre arquitetura e arquivo, que delineamos com o pensamento de Derrida, serve-nos também para compreender que muitas das questões que emergem no processo de pesquisa, são, fundamentalmente, questões a um arquivo. E, com Derrida, ficar ciente de que

"O arquivo, se queremos saber o que isto teria querido dizer, nós só o saberemos num tempo por vir. Talvez. Não amanhã, mas num tempo por vir, daqui a pouco ou talvez nunca. Uma messianidade espectral atravessa o conceito de arquivo e o liga, como a religião, como a história, como a própria ciência a uma experiência muito singular da promessa" (ibid. 50-51).

\section{CONSIDERAÇÕES FINAIS}

As estruturas em negativo que nos encontramos a estudar encerram uma ambiguidade que, sendo constitutiva da realidade arqueológica, é inultrapassável. Há uma diferença na inteligibilidade dos vestígios arqueológicos que é da ordem do inefável (JORGE 2002: 163). O nosso trabalho enquanto arqueólogos faz-se, porém, com essa zona de (des)conhecimento para além da linguagem; faz -se na tentativa de exceder os limites do silêncio dos vestígios e os limites dos discursos face ao que excede a nossa linguagem enquanto atores sociais. Esta transgressão, admitindo o intransponível, é um ensaio de diferentes pontos de vista sobre a "inefável diferença" e ambiguidade dos vestígios (ibid.). A relação entre arquitetura e arquivo é um ponto de partida possível para o desenvolvimento de um desses pontos de vista. A adoção desta perspetiva faz-se porque, nos profícuos caminhos talhados pelo entrelaçamento das práticas de arquivo e de arquitetura, parece existir a possibilidade de se pensar diferentemente um mesmo vestígio e, nesse exercício, trabalhar, como nos sugere M. DE CERTEAU (1982: 93), nos interstícios das diferenças que produzimos no presente e, aí, esboçar uma compreensão da diferença do passado ${ }^{19}$.

\section{AGRADECIMENTOS}

A Susana Soares Lopes e Ana Vale pelas sugestões que nos foram fazendo durante a realização deste trabalho; aos revisores cuja leitura e sugestões críticas contribuíram para o enriquecimento do artigo; a Julia Roberts pela edição do resumo em inglês. À equipa da Arqueologia e Património Lda. que participou nos trabalhos de campo e gabinete que permitiram a apresentação deste trabalho, nomeadamente Flávia Chaves, Maria de Lurdes Oliveira, Nelson Vale, Rodry Mendonça, José Grilo, Liliana Luís, Francisco Barros, João Molha e Cláudio Jorge. A investigação foi apoiada pela Fundação para a Ciência e a Tecnologia com a bolsa de pósdoutoramento SFRH/BPD/100203/2014 - financiada por fundos nacionais do MCTES, POCH e FCE.

\section{BIBLIOGRAFIA}

Alves, C.; Costeira, C.; Estrela, S.; Porfírio, E. \& SERRA, M. 2014. Caracterização preliminar da ocupação pré-histórica da Torre Velha 3 (Barragem da Laje, Serpa). In: A.C. Silva, F.T. Regala e M. Martinho (eds) $4{ }^{\circ}$ Colóquio de Arqueologia do Alqueva. O plano de Rega (2202-2010). Évora, EDIA/ DRCALEN: 103-111.

BAPTISTA, L. 2013. A Idade do Bronze no concelho de Serpa: um primeiro esboço de um conhecimento em construção. In: J. Jimenez Ávila, M. Bustamante, M. Garcia Cabezas (eds), Atas do VI Encuentro de Arqueologia do Suroeste Peninsular. Villafranca de los Barros (Badajoz), Ayuntamiento de Villafranca de los Barros: 669-707.

BAPtista, L.; CunHA, L. \& GoMes, S. 2010. Bloco de Rega de Brinches-Enxoé. Intervenção Arqueológica em Horta da Morgadinha 1. Beja, Histórias \& Tempus Lda.

BAPTISTA, L. \& GOMES, S. 2010a. Bloco de Rega de BrinchesEnxoé. Intervenção Arqueológica em Horta da Morgadinha, Histórias \& Tempus Lda.

\footnotetext{
${ }^{19}$ A palavra arqueologia acolhe também em si a palavra grega arkhê. Acolhe, juntando-a à palavra Logos. Nesta junção, a arqueologia tanto é um estudo do antigo (arkhaia + logia), como uma prática de indagação sobre as possibilidades de começo e comando de discurso (arkhê + logos). Em arqueologia, as palavras e as coisas servem de abrigo à arkhê no sentido de criar a ordem dos discursos; e abrigam-se da arkhê, destruindo a sua instabilidade, para segurar a (i)materialidade de tal ordem. Desta relação entre arkhê e logos, a arqueologia desenvolve a sua atenção relativamente à ambiguidade dos vestígios; (re)conhece as linguagens que se ordem. Desta relação entre arkhêe e logos, a arqueologia desenvolve a sua atenção relativamente à ambiguidade dos vestigios; (re)conhece as linguagens que se
acumulam em processos de criação e destruição, as linguagens que emergem dos entrecruzamentos de diferentes gramáticas e atores. No encontro com a ambiguidade dos vestígios, a arqueologia atenta à inefabilidade da sua diferença (Jorge ibid.), com a qual pode inaugurar um outro discurso. A este propósito, é de referir o pensamento de F. Criado-Boado $(2001,2012)$ sobre os limites, as possibilidades e as condições de conhecimento em arqueologia, no qual o registo arqueológico e entendido como zona de encontro entre a subjetividade dos arqueólogos e as subjetividades daqueles a que o registo se reporta no passado; um encontro que deve ser orientado no sentido da criação de uma terceira subjetividade, que sirva de mediação crítica ao diálogo desse encontro. Forjar esta terceira subjetividade é uma tentativa de criar as condições para um outro discurso; um discurso de congregue e consigne a esquivez da diferença do passado.
} 
BAPTISTA, L. \& GOMES, S. 2010b. Bloco de Rega de Brinches -Enxoé. Intervenção Arqueológica em Espicharrabo 4. Beja, Histórias \& Tempus Lda.

BAPTISTA, L. \& Gomes, S. 2010c. Bloco de Rega de BrinchesEnxoé. Intervenção Arqueológica em Maria da Guarda 3. Beja, Arqueologia \& Património Lda.

BAPTISTA, L. \& Gomes, S. 2010d. Bloco de Rega de Brinches -Enxoé. Intervenção Arqueológica em Monte da Lage. Beja, Histórias \& Tempus Lda.

BAPTISTA, L. \& GOMES, S. 2012a. Trabalhos de minimização de impactes sobre o património cultural decorrentes da execução do Bloco de Rega de Brinches-Enxoé: Relatório Final Global. Beja, Arqueologia \& Património Lda.

BAPTISTA, L. \& GOMES, S. 2012b. Bloco de Rega de Brinches -Enxoé. Intervenção Arqueológica em Lage 2. Beja, Arqueologia \& Património Lda.

BAPTISTA, L. \& GoMES, S. 2012c. Cidade das Rosas 4 (S Salvador, Serpa): contributo para a caracterização dos materiais cerâmicos. In: Actas do $V$ Encontro de Arqueologia do Sudoeste Peninsular, Novembro de 2010. Almodôvar, Município de Almodôvar: 605 614.

BAPTISTA, L. \& GomES, S. 2012d. Vale das Éguas 3 (S. Salvador, Serpa): fragmentação de materiais cerâmicos e enchimento de estruturas. In: Actas do V Encontro de Arqueologia do Sudoeste Peninsular, Novembro de 2010. Almodôvar, Município de Almodôvar: $597-$ 603.

Baptista, L. \& Gomes, S. 2013a. Sítios da Pré-história Recente da Ribeira do Enxoé (Serpa): apontamentos acerca da variabilidade das estruturas em negativo. In: J.M. Arnaud, A. Martins, C. Neves (eds) Arqueologia em Portugal. 150 Anos. Lisboa, Associação dos Arqueólogos Portugueses:351 -359.

BAPTISTA, L. \& GomES, S. 2013b. Contributos para o estudo das modalidades de construção do espaço das "estruturas de planta em osso" e subretangulares alongadas. In: J. Jimenez Ávila, M. Bustamante, M. Garcia Cabezas (eds), Atas do VI Encuentro de Arqueologia do Suroeste Peninsular. Villafranca de los Barros (Badajoz), Ayuntamiento de Villafranca de los Barros: 389-416.

Baptista, L. \& VAle, N. 2017. Circuito Hidráulico de Caliços-Machados e Blocos de Rega. Intervenção Arqueológica em Monte Branco 5. Beja, Arqueologia \& Património Lda.

BARRETT, J. 1994a. Fragments from Antiquity. An archaeology of social life in Britain. $2900-1200$ BC. Oxford, Blackwell Publ.

BARret, J. 1994b. Defining domestic space. The Bronze Age of Southern Britain. In: MP. Pearson e C. Richards (eds) Architecture and Order. Approaches to social space. London, Routledge: 87-97.

Certeau, M. 1982. A escrita da história. Rio de Janeiro, Forense-Universitária.

Chapman, J. 2000. Fragmentation in archaeology: People, places and broken objects in the prehistory of South Eastern Europe. London, Routledge.

Chapman, J. C. \& Gaydarska, B. I. (2007). Parts and wholes. Fragmentation in prehistoric context. Oxford: Oxbow Books.
Chaves, F.; Baptista, L. \& Gomes, S. 2012. Bloco de Rega de Brinches-Enxoé. Intervenção Arqueológica em Horta da Morgadinha 2. Beja, Histórias \& Tempus Lda.

Criado-BoAdo, F. 1993. Espacio monumental y paisajes prehistóricos en Galicia. In: Asociación Galega de Historiadores (ed.) Concepcións espaciais e estratexias territoriais na Historia de Galicia. Santiago de Compostela, Asociación Galega de Historiadores: 2354.

Criado-Boado, F. 2001. Problems, functions and conditions of archaeological knowledge. Journal of Social Archaeology, 1(1): 126-146.

CRIADO-BOAdO, F. 2012. Arqueológicas: la razón perdida: la construcción de la inteligencia arqueológica. Barcelona, Ediciones Bellaterra.

Cunha, L.; BAPTista, L. \& Gomes, S. 2010a. Bloco de Rega de Brinches-Enxoé. Intervenção Arqueológica em Alcaria 4. Beja, Arqueologia \& Património Lda.

Cunha, L.; BAPTISTA, L. \& Gomes, S. 2010b. Bloco de Rega de Brinches-Enxoé. Intervenção Arqueológica em Alcaria 5. Beja, Arqueologia \& Património Lda.

CunHA, L.; BAPTISTA, L. \& Gomes, S. 2010c. Bloco de Rega de Brinches-Enxoé. Intervenção Arqueológica em Cidade das Rosas 4. Beja, Arqueologia \& Património Lda.

Cunha, L.; BAPtista, L. \& Gomes, S. 2010d. Bloco de Rega de Brinches-Enxoé. Intervenção Arqueológica em Vale de Éguas 3. Beja, Arqueologia \& Património Lda.

DerRIDA, J. 2001. Mal de Arquivo. Uma Impressão Freudiana. Rio de Janeiro, Relume Dumará.

DinIz, M. 1999. Povoado neolítico da Foz do Enxoé (Serpa): primeiros resultados. Revista Portuguesa de Arqueologia, 2 (1): 95-126.

EDGEWORTH, M. 2003. Acts of discovery. An ethnography of archaeological practice. Bar International Series 1131. Oxford, Archaeopress.

EDGEWORTh, M. 2006 (ed.). Ethnographies of archaeological practice. Lanham, MD, Altamira Press.

EVANGElista, L. S. 2003. O complexo arqueológico dos Perdigões e a construção da paisagem em Reguengos de Monsaraz. Tese de Mestrado, Universidade do Porto.

Fowler, C. 2004. The Archaeology of Personhood. An Anthropological Approach. London, Routledge.

GARROW, D. 2012. Odd deposits and average practice. A critical history of the concept of structured deposition. Archaeological Dialogues, 19 (2) 85-115.

Gomes, S.; BAptista, L. \& Oliveira, L. 2013a. Práticas de inumação e práticas de construção em Horta da Morgadinha 2 (Salvador, Serpa). In: J. Jimenez Ávila, M. Bustamante, M. Garcia Cabezas (eds), Atas do VI Encuentro de Arqueologia do Suroeste Peninsular. Villafranca de los Barros (Badajoz), Ayuntamiento de Villafranca de los Barros: 261-284.

GOMES, S.; BAPTISTA, L. \& RodRIGUES, L. 2013b. Tradições de inumação durante a Idade do Bronze em Torre Velha 12 (Salvador, Serpa). In: J. Jimenez Ávila, M. Bustamante, M. Garcia Cabezas (eds), Atas do VI Encuentro de Arqueologia do Suroeste Peninsular. 
Villafranca de los Barros (Badajoz), Ayuntamiento de Villafranca de los Barros: 709-732.

Gosden, C. \& MARShall, I. 1999. The cultural biography of objects. World Archaeology, 31 (2): 169-178.

Hallowell, A. I. 1960. Ojibwa ontology, behaviour, and world view. In: F. Diamond. (ed.) Culture in History: Essays in Honor of Paul Radin. New York, Columbia University Press: 17-49.

Henare, A.; HolbraAd, M. \& Wastell, S. (eds) 2007. Thinking through things. Theorising artefacts ethnographically. London, New York: Routledge.

HamiLAKIS, Y. 2017. Sensorial Assemblages: Affect, Memory and Temporality in Assemblage Thinking. Cambridge Archaeological Journal, 27 (1): 169-182.

HAMILAKIS, Y. \& JoNES, A. 2017. Archaeology and assemblage. Cambridge Archaeological Journal, 27 (1): 77-84.

HeIDEGGER, M. 1971. Building Dwelling Thinking. In: M. Heidegger (autor) Poetry, language, thought. New York, Harper and Row: 145-161.

HODDER, I. 2012. Entangled. An archaeology of the relationships between humans and things. Oxford, WileyBlackwell.

INGOLD, T. 2000. Dwelling. In: T. Ingold (autor) The Perception of the Environment. Essays on Livelihood, Dwelling and Skill. London/New York, Routledge: 153-288.

INGOLD, T. 2002. Materials against materiality. Archaeological Dialogues, 14 (1): 1-16.

Jones, A. 2002. Archaeological Theory and Scientific Practice. Cambridge, UK, Cambridge University Press.

Jones, A. 2007. Memory and Material Culture. Cambridge, Cambridge University Press.

Jones, M.; DíAZ-Guardamino, M. \& CREllin, R. 2016. FROM Artefact Biographies to 'Multiple Objects': A New Analysis of the Decorated Plaques of the Irish Sea Region, Norwegian Archaeological Review, 49 (2): 113-133.

JorGE, S.O. 1998a. Contextos e Objectivos do Colóquio. In: S.O. Jorge (coord.) Existe uma Idade do Bronze Atlântica. Lisboa, IPA: 9-10.

JORGE, S.O. 1998b. A lição de um colóquio. In: S.O. Jorge (coord.) Existe uma Idade do Bronze Atlântica. Lisboa, IPA: 283-285.

JoRGE, S.O. 1999. Domesticar a terra. Lisboa, Gradiva.

Jorge, S.O. 2002. Castelo Velho de Freixo de Numão: um recinto monumental pré-histórico do Norte de Portugal. Revista Património. Estudos, 3: 145-164.

Jorge, S.O. 2005. O Passado é Redondo. Dialogando com os sentidos dos primeiros recintos monumentais. Porto, Edições Afrontamento.

JORGE, S.O. 2007. Introdução à sessão 30: Formas de Organização do Espaço e Técnicas de Construção Durante a Pré-história Recente. In: S.O. Jorge, A.M.S. Bettencourt, Ana M. S., I. Figueiral (eds), A concepção das paisagens e dos espaços na Arqueologia da Península Ibérica. Actas do IV Congresso de Arqueologia Peninsular. Faro, Universidade do Algarve: 9-12.
Jorge, V.O. 2003. A irrequietude das pedras. Reflexões e experiências de um arqueólogo. Porto, Edições Afrontamento.

Jorge, V.O.; Cardoso, J.M.; Vale, A.M.; Velho, G. \& PEREIRA, L.S. 2006a (eds). Approaching "prehistoric and protohistoric architectures" of Europe from a "dwelling perspective". Journal of Iberian Archaeology, 8.

Jorge, V.O.; Cardoso, J.M.; Vale, A.M.; Velho, G. \& PEREIRA, L.S. 2006b. Copper Age "monumentalized hills" of Iberia: th shift from positivistic ideas to interpretative ones. New perspectives on old techniques of transforming place and spaces as results of a research experience in the NE of Portugal. In: V.O. Jorge, J.M. Cardoso, A.M. Vale, G. Velho, L.S. Pereira (eds) Approaching "prehistoric and protohistoric architectures" of Europe from a "dwelling perspective", Journal of Iberian Archaeology, 8: 203 264.

Lago, M.; Duarte, C., Valera, A., Albergaria, J., AlmeiDA, F. \& Carvalho, A. 1998. Povoado dos Perdigões (Reguengos de Monsaraz): dados preliminares dos trabalhos arqueológicos realizados em 1997, Revista Portuguesa de Arqueologia, 1 (1): 45-152.

LUCAS, G. 2012. Understanding the archaeological record. New York, Cambridge University Press.

MÁRQUEZ-Romero, J.E. \& JimEnÉZ-JÁImEZ, V. 2010. Recintos de Fosos. Genealogía y significado de una tradición en la Prehistoria del suroeste de la Península Ibérica (IV-III milenios a.C.). Málaga, Servicio de publicaciones de la Universidad de Málaga.

MARTINHO, M. 2014. O Património cultural no Empreendimento de fins múltiplos de Alqueva: caracterizar, avaliar, minimizar, valorizar... In: A.C. Silva, F.T. Regala e M. Martinho (eds) $4 .^{\circ}$ Colóquio de Arqueologia do Alqueva. O plano de Rega (2202-2010). Évora, EDIA/DRCALEN: 34-44.

Mataloto, R. \& Boaventura, R. 2009. Entre vivos e mortos nos IV e III milénios a.n.e. do Sul de Portugal: um balanço relativo do povoamento com base em datações pelo radiocarbono. Revista Portuguesa de Arqueologia, 12 (2): 31-77.

Mataloto, R.; Martins, J.M.M \& SoARES, A.M.M. 2013 Cronologia absoluta para o Bronze do Sudoeste. Periodização, base de dados, tratamento estatístico. Estudos Arqueológicos de Oeiras, 20: 303-338.

Melro, S. \& Deus, M. 2014. O acompanhamento no terreno do Projecto EFMA na área de Extensão de Castro Verde do IGESPAR. In: A.C. Silva, F.T. Regala e M. Martinho (eds) $4{ }^{\circ}$ Colóquio de Arqueologia do Alqueva. O plano de Rega (2202-2010). Évora, EDIA/ DRCALEN: 45-52.

MonTEIRO, N.M.F 2015. O sitio do Monte da Laje (Salvador, Serpa): fossas e fossos na transição do $4^{\circ}$ para o $3^{\circ}$ milénio a.n.e. na bacia média do Guadiana. Tese de Mestrado, Universidade de Lisboa.

Muralha, J. 2010. Castanheiro do Vento (Horta do Douro, Vila Nova de Foz Côa) - Um Recinto Monumental do III ${ }^{o}$ e II ${ }^{o}$ milénio a.C.: Problemática do Sitio e das suas Estruturas à Escala Regional. Maiorca, Editorial Vessants.

OLSEN, B. 2010. In defense of things. Archaeology and the Ontology of objects. Lanham, Altamira Press. 
Olsen, B.; Shanks, M.; Webmoor, T. \& Witmore, C. 2012. Archaeology. The discipline of things. Berkeley: University of Califorina Press.

Parreira, R. 1983. O Cerro dos Castelos de São Brás (Serpa). Relatório preliminar dos trabalhos arqueológicos de 1979 e 1980. O Arqueólogo Português, série IV, 1: 149-168.

PEARSON, M.P. \& Richards, C. (eds) 1994. Architecture and Order. Approaches to social space. London, Routledge.

Porfírio, E. \& SERrA, M. 2012. Arroteia 6 (Mombeja, Beja) no contexto da Idade do Bronze do Sudoeste Peninsular. In: Actas do V Encontro de Arqueologia do Sudoeste Peninsular, Novembro de 2010. Almodôvar, Município de Almodôvar: 25-38.

ReBUGE, J. 2004. Uma proposta para reconceptualizar a materialidade arqueológica: o campaniforme no norte de Portugal e regiões contíguas. Trabalhos de Antropologia e Etnologia, 44 (1-2): 111-186.

RENFREW, C. 1998. Varna and the emergence of wealth in prehistoric Europe. In: I. Appadurai (ed) The Social Life of Things: Commodities in Cultural Perspective. Cambridge, Cambridge University Press: 149168.

RoDrigues, A.F. \& MARTINS, A.C. 2005. O povoado NeoCalcolítico de Casa Branca 7 (Serpa): resultados preliminares. In: R. Ontañón Peredo, C. GarcíaMoncó Piñeiro, P. Arias Cabal (coords) Actas do III Congreso del Neolitico em la Península Ibérica. Santander, Universidade de Cantabria: 957-964.

SANTOS, A. 2008. Uma abordagem hermenêtica Fenomenológica à Arte Rupestre da Beira Alta: o caso do Fial (Tondela, Viseu). Viseu, Centro de Estudos Pré-históricos da Beira Alta.

Santos, F.; Arez, L.; SoAres, A.M.; Deus, M.; QueIroZ, P.F.; VAlério, P.; Rodrigues, Z.; ANTUNES, A.S. \& ARAÚJO, M.F. 2008. O Casarão da Mesquita 3 (S. Manços, Évora): um sítio de fossas "silo" do Bronze Pleno/Final na Encosta do Albardão. Revista Portuguesa de Arqueologia, 11 (1): 55-86.

SChUBART, H. 1975. Die Kultur der Bronzezeit im Südwesten der Iberischen Halbinsel. Berlim, Wolter de Gruyter \& Co. (Madrider Forschungen. 9).

SCHIFFER, M. 1987. Formation processes of the archaeological record. Albuquerque, NM, University of New Mexico Press.

SILVA, A.C. 2014. Alqueva - Quatro encontros de arqueologia depois... In: A.C. Silva, F.T. Regala e M. Martinho (eds) $4 .^{\circ}$ Colóquio de Arqueologia do Alqueva. O plano de Rega (2202-2010). Évora, EDIA/ DRCALEN: 19-33.

Silva, C. T. \& SoARES, J. 1981. Pré-história da área de Sines. Lisboa, Gabinete da Área de Sines.

SILVA, S. 2014. As cerâmicas do Outeiro do Circo (Beja): resultados do estudo tecnológico, formal e decorativo. In. R. Vilaça e M. Serra (Coord.) Idade do Bronze do Sudoeste Novas perspetivas sobre uma velha problemática. Coimbra, IA|SA|FLUC / Palimpsesto Lda. / CEAACP: 167-186.

SoARES, A.M. 1992. O povoado calcolítico de Três Moinhos (Baleizão, conc. de beja). Notícia Preliminar. Setúbal Arqueológica, 9-10: 291-314.
SOARES, A.M. 1994. O Bronze do Sudoeste na Margem Esquerda do Guadiana. As Necrópoles do Concelho de Serpa. In: Associação dos Arqueólogos Portugueses (ed.), V Jornadas Arqueológicas. Volume II. Lisboa, AAP: 179-197.

SOARES, A.M. 2005. Os povoados do Bronze Final do Sudoeste na margem esquerda portuguesa do Guadiana: novos dados sobre cerâmica de ornatos brunidos. Revista Portuguesa de Arqueologia, 8 (1): 111-145.

SoARES, A.M. 2008. O monumento megalítico Monte da Velha 1 (MV1) (Vila Verde de Ficalho, Serpa). Revista Portuguesa de Arqueologia, 11 (1): 33-51.

SOARES, A.M. 2013. O sistema de povoamento do Bronze Final no Baixo Alentejo na bacia do Guadiana. Estudos Arqueológicos de Oeiras, 20, 2013: 273 302 .

SOARES, A.M. \& ARNAUD, J.M. 1984. Escavações do Sepulcro Megalítico MV2 (V.N. Ficalho, Serpa). Arquivo de Beja, série I, II: 67-82.

SOARES, J. 2014. Transformações sociais durante o III milénio AC no Sul de Portugal. O povoado do Porto das Carretas. Évora, EDIA/DRCLAEN.

SoAreS, J. \& Silva, C. T. 1992. Para o conhecimento dos povoados do megalitismo de Reguengos. Setúbal Arqueológica, 9-10: 37-88.

SOARES, R.M.; BAPTISTA, L. \& RODRIGUES, Z. 2016. Os primeiros enterramentos sidéricos conhecidos na margem esquerda do Guadiana em território português. Revista Portuguesa de Arqueologia, 19: 129-141.

SousA, A.C., 2010. O Penedo do Lexim e a sequência do neolítico final e calcolitico da Península de Lisboa. Tese de Doutoramento, Universidade de Lisboa.

Thomas, J. 1999. Understanding the Neolithic. London, Routledge.

SHANKS, M. 1992. Experiencing the past. On the character of archaeology. London/New York, Routledge.

SHANKS, M. 2012. The archaeological imagination. Walnut Creek, California, Left Coast Press, Inc.

VALE, A.M.A 2011. Modalidades de produção de espaços no contexto de uma colina monumentalizada: o sitio pré-histórico de Castanheiro do Vento, em Vila Nova de Foz Côa. Tese de Doutoramento, Universidade do Porto.

VALE, A. 2015. Genealogia, tradução e paradigma na construção da arqueologia pré-histórica. Estudos do Quaternário, 13, 48-54.

VAlera, A.C. 2007. Dinâmica locais de identidade: estruturação de um espaço de tradição no $3 .^{\circ}$ Milénio AC (Fornos de Algodres, Guarda). Fornos de Algodres, Município de Fornos de Algodres / Terras de Algodres - Associação de Promoção do Património de Fornos de Algodres.

VALERA, A.C. 2008. Discurso cientifico em arqueologia: a necessidade de o conhecimento cientifico se conhecer. Lisboa, NIA - Era Arqueologia SA.

VALERA, A.C. 2012. Fossos sinuosos da Pré-história Recente do Sul de Portugal: ensaio de análise crítica. In Actas do V Encontro de Arqueologia do Sudoeste Peninsular, Novembro de 2010. Almodôvar, $\mathrm{Mu}-$ nicípio de Almodôvar: 25-38. 
VALERA, A.C. 2016. Ditched enclosures and the ideologies of death in the Late Neolithic and Chalcolithic South Portugal. In: V. Ard e L. Pillot (eds) Giants in the Landscape: Monumentality and Territories in the European Neolithic. Proceedings of the XVII UISPP World Congress (September, Burgos, Spain). Oxford, Archaeopress Publishing Ltd.: 6984 .

VALERA, A.C. \& FiLIPE, V. 2012. A necrópole de hipogeus do Neolítico Final do Outeiro Alto 2 (Brinches, Serpa). Revista Apontamentos, 8: 29-41.

VALERA, A.C. 2013. O Bloco 5 do Plano de Minimização. In: A.C. Valera (ed.) As sociedades agro-pastoris na margem esquerda do Guadiana. Évora, EDIA DRCALEN: 17-21.

VAlera, A.; Godinho, R.; Ever CAlvo, F.; MORo BerraQUERO, J.; FILIPE, V. \& SANTOS, H. 2014. Um mundo em negativo: fossos, fossas e hipogeus do Guadiana (Brinches, Serpa). In: A.C. Silva, F.T. Regala e M. Martinho (eds) $4 .^{\circ}$ Colóquio de Arqueologia do Alqueva. O plano de Rega (22022010). Évora, EDIA/DRCALEN: 55-73.
Velho, G.L. 2009. Castelo Velho, a Natureza e o Tempo: questões relativas à re-construção de um lugar. Tese de Doutoramento, Universidade do Porto.

ZEMELMAN, H. 2003. Sujeito e Sentido: considerações sobre a vinculação do sujeito ao conhecimento que constrói”. In: B. Sousa Santos (org.) Conhecimento Prudente para uma Vida Decente. "Um discurso sobre as Ciências” revisitado. Porto, Edições Afrontamento, 435-446.

Zemelman, H. 2011. Los horizontes de la razón III. El orden del movimiento. Barcelona, Anthropos Editorial.

Zemelman, H. 2012a. Los horizontes de la razón I. Dialéctica y apropiación del presente. Barcelona Anthropos Editorial.

Zemelman, H. 2012b. Los horizontes de la razón II. Historia y necesidad de utopia. Barcelona, Anthropos Editorial. 